\title{
Pollution potential and causative hydrogeochemical processes in unconfined aquifer systems in a typical urban setting: emphasis on recharge and discharge areas
}

\author{
Y. A. Asiwaju-Bello ${ }^{1}$ O. F. Olabode ${ }^{1} \cdot$ M. T. Ogunsuyi ${ }^{2}$
}

Received: 19 September 2019 / Accepted: 23 December 2019 / Published online: 6 January 2020

(c) The Author(s) 2020

\begin{abstract}
The inhabitants of Akure Metropolis, south-western Nigeria, depend solely on groundwater for their domestic, industrial and irrigation purposes. There is a need to delineate recharge and discharge areas for assessment and management of groundwater in these areas. One hundred and ninety (190) dug wells were selected for this assessment. Elevation and water table data aided accurate delineation of recharge, discharge and groundwater divide areas. Thirty-six wells representative of recharge and discharge areas were subjected to pollution assessment [DRASTIC, water quality index (WQI) and runoff potential]. The results revealed that the recharge areas have higher pollution potential and runoff amount than the discharge areas. This implied that groundwater sourced from recharge areas was more pollution prone than that sourced from discharge areas. WQI results revealed that the waters from recharge and discharge areas fall within excellent, good, poor, and unsuitable quality categories. Hydrogeochemical results revealed that concentrations of cations and anions are in order of $\mathrm{Ca}^{2+}>\mathrm{Mg}^{2+}>\mathrm{K}^{+}>\mathrm{Na}^{+}$ and $\mathrm{HCO}_{3}{ }^{-}>\mathrm{Cl}^{-}>\mathrm{SO}_{4}{ }^{2-}$ with a predominant $\mathrm{Ca}-\mathrm{HCO}_{3}$ facies typifying water from a basement complex environment. Gibbs plot and chloro-alkaline index affirmed the rock dominance and existence of imprints of ion-exchange processes influencing the groundwater quality. Intense weathering activities aided with long resident time spent by the water in the voids of the aquifer media are characteristic in this terrain. Recharge of precipitating water through infiltration into the weathered basement aquifers is a pointer to the greater yield of water in the wells. The possibility that precipitation-weathering process has led to the increase in concentrations of all ionic species and possible pollution of the groundwaters from the recharge and discharge areas cannot be ruled out at all.
\end{abstract}

Keywords Groundwater $\cdot$ Recharge $\cdot$ Discharge $\cdot$ Hydrogeochemical facies $\cdot$ Pollution assessment

\section{Introduction}

It has been projected that by the year 2030, the world population will have geometrically risen to 8.5 billion, of which $60 \%$ of this population will reside in urban areas (UNDESAPD 2015). As a matter of fact, urban cities are evidently the engines of the world's economic development. Urban land mass comprises a wide diversity of land use practices (e.g. commercial hubs, educational institutions and

O. F. Olabode

ofolabode@futa.edu.ng

1 Applied Geology Department, The Federal University of Technology, Akure, Nigeria

2 Marine Science and Technology, The Federal University of Technology, Akure, Nigeria residential areas, etc.) with its consequential effects. One of the many consequential effects occurs in the form of modification of recharge rate, pattern and groundwater quality with high prevalence in urban areas as compared to rural areas (Foster et al. 1998; Oke 2015).

However, there is evidently high demand for water from these increasing urban populace. This is due to their economic activities and commercial enterprises (MacDonald et al. 2005), and total reliance on groundwater for varied purposes. This high demand has been sourced from several hand-dug wells and borehole systems which were mostly or sometimes ill-designed, ill-constructed and non-maintained water systems leading to groundwater pollution and groundwater scarcity in recharge and discharge areas (Ocheri 2006; Ocheri and Mile 2010). Several works have attributed the increased records of groundwater contamination and pollution in the urban cities to several urban human activities 
(anthropogenic sources). These have been categorized into the following: high population of individuals, increasing industrial and agricultural activities such as leakages from underground storage tanks, chemicals and waste dump-sites, industrial effluents, sewage pits, land spreading of sludge, brine disposal from the petroleum industry, mine waste, animal feeds, radioactive waste, highway run-offs and acidic rain; which has also been found to be associated with various deadly diseases (Kehinde 1998; Punmia and Jain 1998; Sridhar 2000; Adelana et al. 2003, 2004, 2005, 2008; Ikem et al. 2002; Akujieze et al. 2003; Ajala 2005; Ocheri 2006; Gbadebo et al. 2010; Eni et al. 2011; Naidu et al. 2011; Ocheri et al. 2014; Laniyan et al. 2015). Furthermore, the impact of natural activities (leaching and rock weathering) on urban groundwater quality cannot also be underrated in urban areas.

Groundwater recharge and discharge areas serve as important areas for drinking, industrial and agricultural purposes. These areas are also vulnerable to pollution (Owoseni et al. 2013). The delineation of these areas can be attributed solely to the direction of groundwater locally and regionally (Freeze and Cherry 1979; Fetter 1994). Co-occurrence of recharge and discharge areas depends on the type of geological and hydrogeological setting influencing groundwater flow and direction. Ignorantly, urban populace in the fight for survival site their houses, companies and institutions in these areas endangering the natural resource (groundwater) in Akure Metropolis.

Many researchers (Olorunfemi et al. 1999; Akintorinwa and Olowolafe 2012; Anifowose and Kolawole 2012; Asiwaju-Bello et al. 2013; Owoseni et al. 2013; Owoseni and Komolafe 2014; Aladejana et al. 2016; Yenne et al. 2018) have worked on the several aspects of groundwater resources of Akure area for different purposes. However, they did not consider the identification and assessment of the groundwater recharge and discharge areas in Akure area. Lawrence and Upchurch (1982) employed geochemical factor analysis for the identification of recharge areas of Floridan Aquifer, the USA. Other studies (e.g. Mahmoud 2014; Senanayake et al. 2016) used remote sensing and GIS tools in the delineation of groundwater recharge and discharge areas. DRASTIC approach has practically been employed for the quantification of groundwater susceptibility all over the world (Hernandez-Espriu et al. 2014). Cautiously, Villumsen et al. (1983) emphasized that the chemical composition of groundwater can be used as an indicator of vulnerability, which can also serve for preliminary verification/validation of the vulnerability maps produced by different vulnerability approaches such as AVI, DRASTIC, GOD, IRISH and SINTACS.

Groundwater pollution assessment studies have aided accurate assessment of the vulnerability of groundwater to pollution coupled with in-depth understanding and knowledge of hydrogeochemical processes which have been found important in groundwater quality assessment. Hydrogeochemical processes greatly influence the pollution or contamination of groundwater all over the world (Krishna Kumar et al. 2014; Batabyal and Chakraborty 2015; Adewumi et al. 2018; Batabyal 2017; Lapworth et al. 2017; Olofinlade et al. 2018; Oyedele et al. 2019). This study is, however, aimed at the delineation of groundwater recharge and discharge areas in an urban metropolis, like Akure, the capital city of Ondo State, south-western Nigeria, for their pollution potential as well as the hydrogeochemical processes prevailing in the area. This will be achieved with pollution assessments such as DRASTIC, water quality index (WQI), runoff potential (RP) and multivariate statistical analyses (descriptive, principal component analyses, hierarchical cluster analyses and correlation analyses). Piper diagram, Gibbs plot and Chloro-Alkaline Index were employed to understand the hydrogeochemical processes in the waters. This study will support the protection of these unconfined aquifers from several urban activities that can endanger the populace that consume these waters.

\section{Drainage, climate, vegetation and topography of the study area}

Akure, a Metropolitan city of Ondo State in south-western part of Nigeria, lies within latitudes $07^{\circ} 12^{\prime}$ and $07^{\circ} 19^{\prime} \mathrm{N}$ and longitudes $005^{\circ} 8^{\prime}$ and $005^{\circ} 17^{\prime} \mathrm{E}$ with total area coverage of $217.41 \mathrm{~km}^{2}$ (Fig. 1). Akure area is, however, drained by River Ala with its dense tributaries of streams forming dendritic drainage system of flow in two directions namely south-eastern and north-western (Asiwaju-Bello et al. 2013) (Fig. 1). Akure area experiences two seasons in a year: the wet and dry seasons. The wet season spans between April and September, but March to November receives most of the fall which is evident by an excess of $40 \mathrm{~mm}$ on a single day, while the dry season period is from October to March. The main rain-bearing system affecting the area is embedded in the easterly wind current. The average annual rainfall is $1309.6 \mathrm{~mm}$ (OSMEPB 2012). Annual temperature for Akure area ranges from 18 to $31{ }^{\circ} \mathrm{C}$, respectively. Evaporation is usually low from June through September, ranging from 3.3 to $4.5 \mathrm{~mm} /$ day. Sunshine duration is short (2.7-2.9 h/day) during the month of July to September, while the relative humidity ranges from 5.0 to $90 \%$, depending on the season (OSMLHE 2000). Akure's vegetation is characterized with regrowth rainforest type evident as grasses and trees. There is a varied topography with high elevation at the southern part and pockets of hills found in the north-eastern part of the study area ranging from 315 to $402 \mathrm{~m}$ above mean of sea level (Faniran 1970; AsiwajuBello et al. 2013) (Fig. 1). 


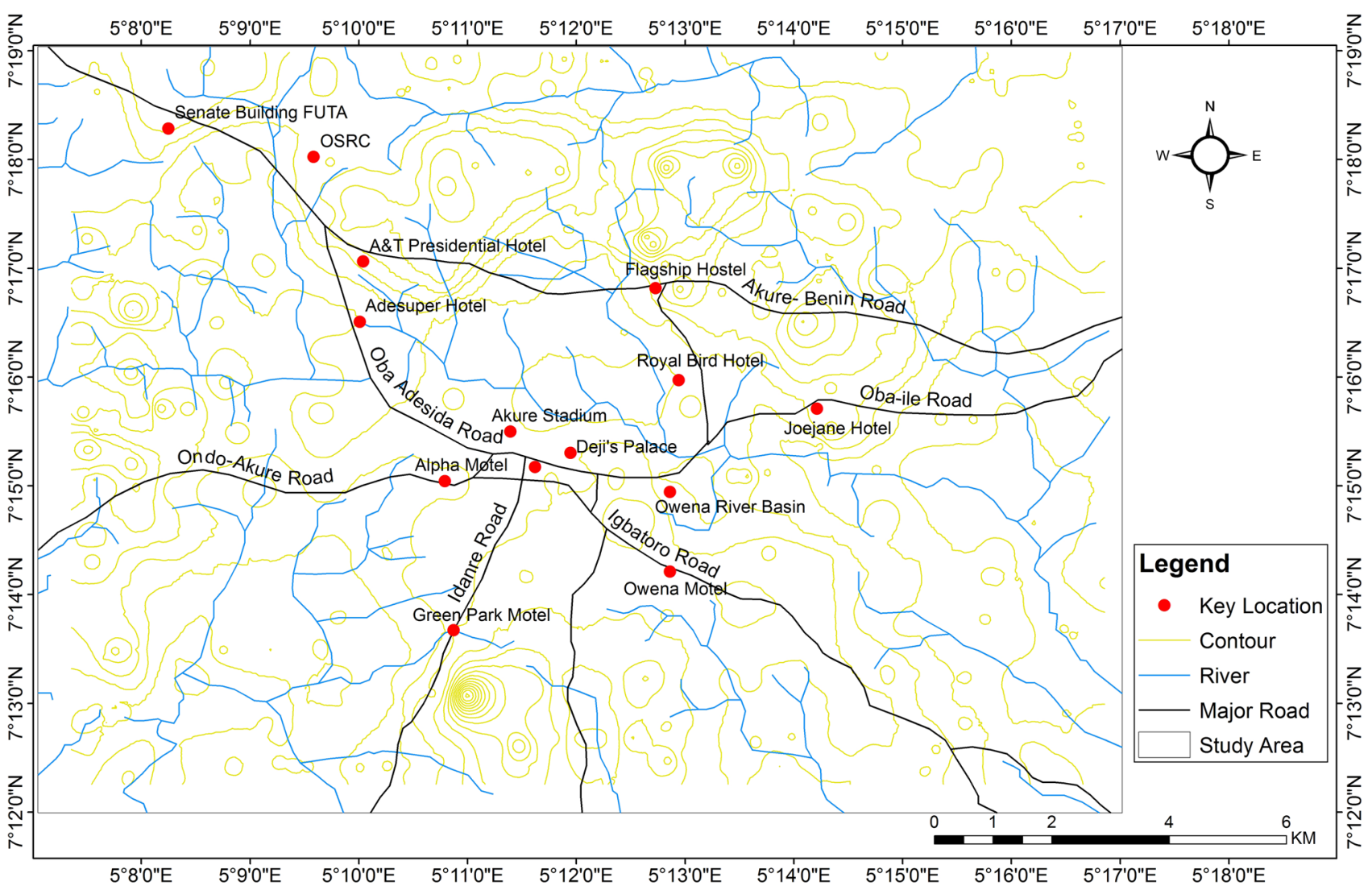

Fig. 1 Topographical map of the study area

\section{Geologic and hydrogeologic settings of the study area}

Akure area is underlain by basement rocks of south-western Nigeria such as quartzite, granite gneiss, porphyritic granite and charnockite (Rahaman 1976; Anifowose 2000) (Fig. 2). Overburden of thick weathered regoliths which varies from place to place overlay these rocks in some places. These rocks generally lack primary porosity but possess secondary porosity due to weathering and fracturing activities (Acworth 1987; Olorunfemi et al. 1999; Owoseni et al. 2013; Aladejana et al. 2016). Groundwater recharge is primarily through infiltration by direct precipitation with mean annual value of about $1350 \mathrm{~mm}$. Secondary recharge occurs by influent flow condition from Ala River and its tributaries. Groundwater discharge in Akure area occurs through seepages, springs, well water abstraction, and flow into surface water bodies (rivers and streams) (Owoseni et al. 2013). Groundwater is usually sourced through hand-dug wells and bore hole with variable yield. The aquifers of Akure area are weathered and fractured aquifers typical of any crystalline basement terrain (Olabode 2019).

\section{Materials and methods}

One hundred and ninety (190) shallow hand-dug wells scattered all around Akure area were initially selected for the study during well campaign. The approach employed for this study follows a sequential stages from well campaign, water table mapping, water level measurement, pollution assessment [DRASTIC and runoff potential (RP)], physiochemical, cationic and anionic species determination, water quality index, Gibbs plot and multivariate statistical analysis. The procedures are explained in different sections.

\section{Water level measurement}

Water level indicator was used to measure the level of water in all the selected one hundred and ninety (190) hand-dug wells of the study area. The data obtained were then related to mean sea level and used in the generation of water table distribution map for the area. The groundwater levels and flow direction were plotted in the form of a map using Surfer software version 10 . The local groundwater flow directions and its flow vectors were deduced from the map, which was later used in the identification of groundwater recharge, discharge and divide areas. 


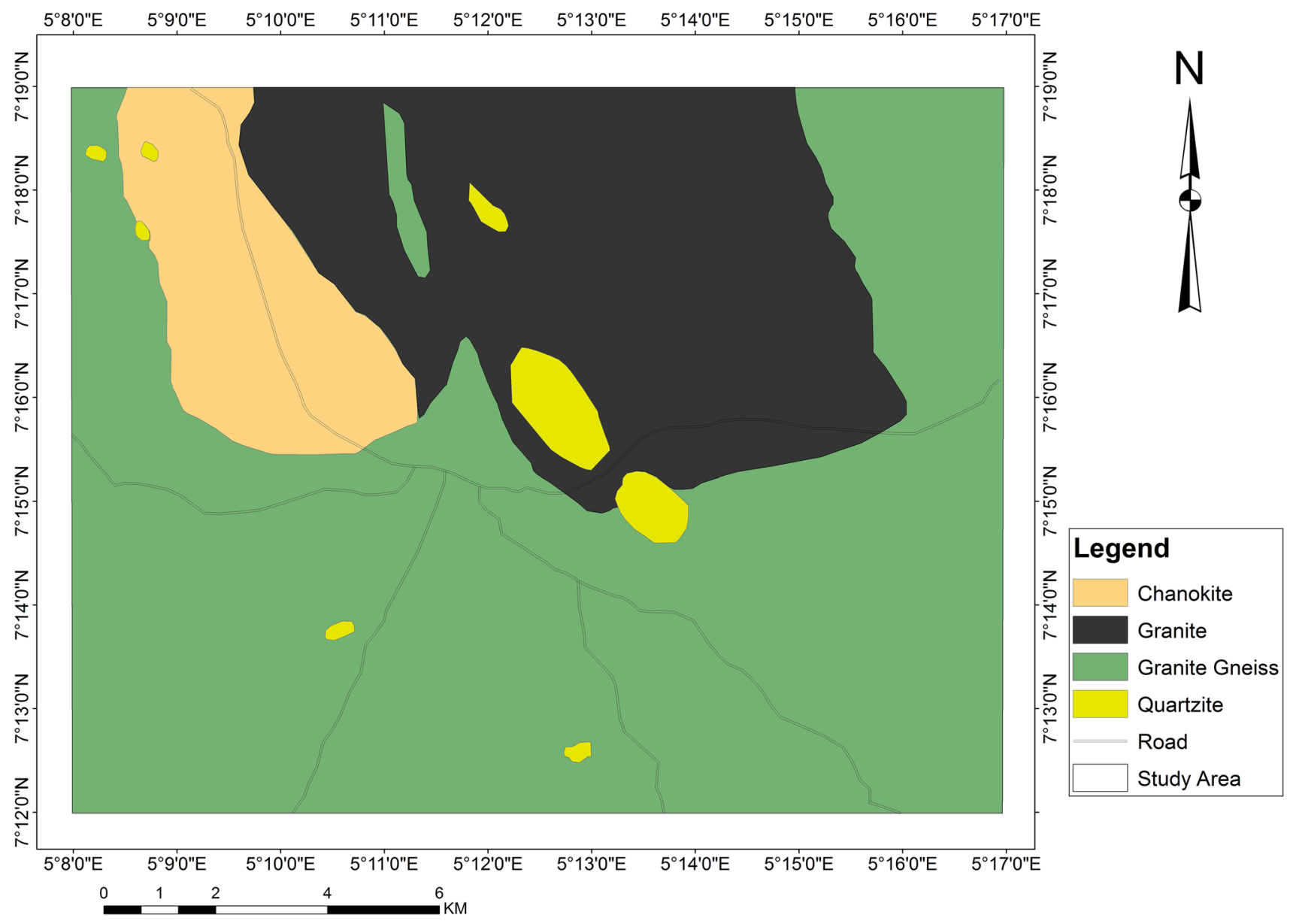

Fig. 2 Geological map of Akure area (NGSA 2006)

\section{DRASTIC}

DRASTIC, a score-based, empirical (numerical ranking) and parametric system which assigns weights and ratings to all the seven knowledge-based hydrogeological parameters, was used for the pollution potential assessment of the unconfined aquifer systems due to its large extent (regional scale) in an urban setting like Akure area (Aller et al. 1987; Oke 2015). The seven knowledge-based worldwide accepted hydrogeological factors considered in the study are depth to groundwater $(D)$, net recharge rate $(R)$, aquifer media $(A)$, soil media $(S)$, topography/slope $(T)$, impact of the vadose zone $(I)$ and hydraulic conductivity of the aquifer $(C)$. The values of the ratings and weights for each hydrogeological parameter were plugged into Eq. 1 to determine the pollution potential for all the recharge and discharge areas otherwise known as the DRASTIC Index (Aller et al. 1987).

$P=D r D w+R r R w+A r A w+S r S w+T r T w+I r I w+C r C w$ where $P$ is the pollution potential and the small letters $r$ and $w$ are the corresponding ratings and weights, respectively. The calculated DRASTIC Index used in the study was referred to as pollution potential which enabled the possibility of identifying areas that are vulnerable to groundwater pollution. However, areas characterized with higher DRASTIC Index values are posed to be highly vulnerable with greater propensity of aquifer contamination. Unarguably, the DRASTIC Index/pollution potential had been further categorized into three vulnerability groups, namely low, moderate and high (Owoseni and Komolafe 2014).

\section{Runoff classification using SCS-CN}

Curve number $(\mathrm{CN})$, a coefficient, was employed in the determination of runoff potential of Akure area and its effect on the recharge and discharge areas. This was found on the equation for water balance in Eqs. 2 and 3 (Deshmukh et al. 2013; Soulis and Valiantzas 2012)

$$
P=I_{\mathrm{a}}+F+Q
$$


$\frac{Q}{P-I_{\mathrm{a}}}=\frac{F}{S}$

The expression of SCS-CN was obtained from the following equations

$Q=\frac{\left(P-I_{\mathrm{a}}\right)^{2}}{\left(P-I_{\mathrm{a}}\right)}+S \quad$ if $P>I_{a}$

$Q=0$, otherwise $I_{\mathrm{a}}=\lambda S$ where direct runoff $(\mathrm{mm})$ is $Q$, total precipitation (mm) is $P$, initial abstraction $(\mathrm{mm})$ is $I_{\mathrm{a}}$, potential maximum retention ( $\mathrm{mm}$ ) is $S$, actual retention after runoff commences is $F$, and lastly, the abstraction coefficient (dimensionless) is $\lambda$.

$S=\left(\frac{25400}{\mathrm{CN}}\right)-254$

Curve number $(\mathrm{CN})$ is influenced by the soil type and subsoil condition, land cover, and condition of the hydrological regime of the area under study.

The land use/cover image and hydrological soil group (HSG) were used in the runoff analysis. The runoff potential of Akure area was generated by the intersection of the land cover and soil maps. $\mathrm{CN}$ value usually ranges from 0 to 100 , and the increasing value of $\mathrm{CN}$ signifies the reduction in infiltration amount and high amount of runoff (Aladejana et al. 2016). However, this assertion is due to the combined influence of the prevailing slope, soil type and subsoil conditions, density of vegetation, rate of human activities and intensity of rainfall and hydrological regime of the area under investigation. Curve number estimation for Akure area followed the method of Aladejana et al. (2016).

\section{Physiochemical, cationic and anionic species determination}

Parameters such as temperature, electrical conductivity, total dissolved solids (TDS) and hydrogen ion concentration $(\mathrm{pH})$ were measured in situ using EC/pH/TDS-temperature meter in the groundwater samples. Flame photometer was used to determine the dissolved concentrations of calcium, magnesium, sodium and potassium ions in the groundwater samples. Turbidimetric technique using spectrophotometer that was used in the determination of dissolved concentrations of bicarbonate, chloride and sulphate ions was carried out in the Geochemistry laboratory of the Applied Geology Department of the Federal University of Technology, Akure, Ondo State, Nigeria, following APHA standard (1995).

\section{Water Quality Index (WQI) approach}

Hydrochemical data were subjected to water quality index (WQI) evaluation, a rating technique that provides the composite influence of individual water quality parameters such as anions $\left(\mathrm{HCO}_{3}{ }^{-}, \mathrm{Cl}^{-}\right.$and $\left.\mathrm{SO}_{4}{ }^{2-}\right)$ and cations $\left(\mathrm{Ca}^{2+}, \mathrm{Mg}^{2+}\right.$, $\mathrm{Na}^{+}$, and $\mathrm{K}^{+}$) on the overall quality of water. For the calculation of WQI, World Health Organization (2011) drinking water standard was considered. Assumption was made for the assigned water quality parameters weightage to be indirectly of standard recommendations for these parameters. Vasanthavigar et al. (2010) approach was employed in the assignment of weights to the chemical variables in the following manner. Maximum weight of 4 has been assigned for sulphate and electrical conductivity, 3 for bicarbonate and chloride, 2 for calcium, sodium and potassium and 1 for magnesium.

The quality rating scale for each parameter, Qi, was calculated by using this expression (Eq. 6):

Quality rating $\mathrm{Qi}=100\left(\frac{\mathrm{Vn}-\mathrm{Vi}}{\mathrm{Vs}-\mathrm{Vi}}\right)$

where $\mathrm{Q} i=$ quality rating, $\mathrm{Vn}=$ measured values of the chemical variables (e.g. dissolved cations and anions), $\mathrm{Vi}=$ initial values for all the chemical parameters, it is zero for all the chemical parameters but 0 and 14.6 for $\mathrm{pH}$ and dissolved oxygen, respectively, and $\mathrm{Vs}=$ standard value for all the chemical variables according to WHO 2011 standard. Relative weight (Wi) was calculated by a value inversely proportional to the recommended standard $(\mathrm{Si})$ of the corresponding parameter.

$\mathrm{Wi}=\frac{K}{\mathrm{Si}} \quad$ where $K=\frac{1}{\sum\left(\frac{1}{\mathrm{Si}}\right)}$

where $\mathrm{Wi}=$ weight, $\mathrm{Si}=$ standard value for all the chemical variables such as TDS, $\mathrm{EC}, \mathrm{Ca}, \mathrm{Mg}, \mathrm{Na}, \mathrm{K}, \mathrm{HCO}_{3}, \mathrm{Cl}, \mathrm{SO}_{4}$ according to WHO 2011 standard, $K=$ constant. The overall WQI was calculated using Eq. 4

Water Quality Index WQI $=\frac{\sum \mathrm{Qi}}{\sum \mathrm{Wi}}$

The WQI range and type of water were classified according to Adewumi et al. (2018) (Table 4).

\section{Hydrogeochemical processes and evolution approach}

The hydrogeochemical processes and evolution of groundwater in Akure area were achieved through Chloro-Alkaline Index (CAI), Gibbs and Pipers plot. 


\section{lon-exchange approach}

Chloro-Alkaline Index was employed to determine the types of ion-exchange processes at play in the waters of Akure area according to Schoeller (1967).

$\mathrm{CAI}=\frac{\mathrm{Cl}-\mathrm{Na}+\mathrm{K}}{\mathrm{Cl}}$

where the concentrations of $\mathrm{Cl}, \mathrm{Na}$ and $\mathrm{K}$ are in meq/l

\section{Gibbs plot approach}

Gibbs diagram was employed in order to establish relations prevailing between water composition and aquifer lithological characteristics, identify the dominant geochemical processes and mechanisms prevailing in waters sourced from recharge and discharge areas with strong replication of a particular environment. These relations, geochemical processes and mechanisms have a strong effect on the overall quality of water usage and can also guide towards its remediation if water quality is found unsuitable for many varied purposes (Gibbs 1970; Olofinlade et al. 2018). The Gibbs diagram consists of three different zones, namely evaporation, atmospheric (precipitation) and rock-water interaction dominance (Gibbs 1970). Accurate Gibbs plots for recharge and discharge of Akure area were obtained by the plots of TDS against ionic ratios $\left(\mathrm{Na} /(\mathrm{Na}+\mathrm{Ca})\right.$ and $\mathrm{Cl} /\left(\mathrm{Cl}+\mathrm{HCO}_{3}\right)$.

\section{Water type approach}

The chemical results obtained from the chemical analysis were computed and plotted on the Piper diagram (Piper 1944) using the USGS GW Chart software. The Piper diagram was used in the determination of the predominant water facie type of recharge and discharge areas of Akure area.

\section{Multivariate statistical analysis}

The obtained concentrations of dissolved ions for recharge and discharge areas were subjected to multivariate statistical analyses. These analyses are known for their ability to illuminate the relations between the individual chemical variables, thereby providing insight into the compositional dissimilarity between the water chemistry and establishment of various controlling factors influencing the chemistry of the aquifers. This is achieved in Excel and IBM SPSS Statistics 18 environments.

\section{Descriptive analysis}

This describes the hydrochemical data set with respect to minimum, maximum, mean and standard deviation values for all the nine (9) chemical variables such as EC, TDS, Ca, $\mathrm{Mg}, \mathrm{Na}, \mathrm{K}, \mathrm{HCO}_{3}, \mathrm{SO}_{4}{ }^{2-}$ and $\mathrm{Cl}$ and other variables such as Chloro Alkaline Index for the present study.

\section{Correlation analysis}

This analysis was performed using Excel software, where all the chemical variables were inputted in order to establish relationship between them. This relationship will provide information about the quality and evolution of the waters in the recharge and discharge areas. A pair of chemical variables having correlation coefficient lower than 0.5 suggests no weighty connection, while greater than 0.5 and equal to 0.8 depicts strong connection and greater than or equal to 0.8 depicts a very strong connection. The correlation analysis employed in the interpretation of the results presented on the correlation table was carried out after Jeyaraj et al. (2006).

\section{Principal component analysis and hierarchical cluster analysis}

Principal component analysis (PCA) and hierarchical cluster analysis (HCA) were employed for this study using the statistical software package (IBM Statistics 18). Principal component analysis is usually aimed at reduction in the hydrochemical data to a smaller number without loss of necessary facts. It also converts the data matrix into a new set of fused variables [principal components (PCs)] based on variance-covariance matrix. The variance and covariance of chemical parameters are determined based on standardized data. The PCs are by definition uncorrelated with each other. The chemical variables used for PCA were electrical conductivity (EC), total dissolved solids (TDS), $\mathrm{Ca}^{2+}, \mathrm{Mg}^{2+}, \mathrm{Na}^{+}, \mathrm{K}^{+}, \mathrm{HCO}_{3}{ }^{-}, \mathrm{SO}_{4}{ }^{2-}$ and $\mathrm{Cl}^{-}$. PCs with eigenvalues greater than 1 were only extracted, while those lower than 1 were eliminated following the assumption of Chatfield and Collin (1980). Calculated components loadings, eigenvalues, $\%$ total variance and cumulative variance and scree plots of the eigenvalues of observed components were extracted and represented, which were then subjected for interpretation. Marghade (2015) classification of positive PC loadings was employed in the classification and interpretation of the delineated principal components (PCs) loadings for the recharge and discharge areas. The PC loadings are classified as thus very low positive PC loadings with value lower than 0.45 , low-positive PC loadings with values ranging between 0.45 and 0.6 , medium-positive 
PC loadings with values ranging between 0.6 and 0.75 , high-positive PC loadings with values ranging between 0.75 and 0.90 and very high positive PC loadings with values greater than 0.9 .

For Q-mode hierarchical cluster analysis (HCA), ward linkage (rescaled distance cluster combine) method was employed which aided the clustering and delineating of similarities between the wells. This method recognized relatively homogeneous groups of locations based on the chemical variables. This was achieved through the aid of two dendrograms representative of recharge and discharge areas of Akure.

\section{Results and discussion}

The water table head and flow vector distribution map generated for the area are presented in Fig. 3. Deductions from Fig. 3 enabled the identification of six recharge and discharge areas as well as several divide areas. The recharge areas are designated as R1-R6, while the discharge areas are designated as D1-D6 (Fig. 3). The groundwater flow is localized in the form of discrete bodies (replicate of pockets or mini-basins), which are structurally and topographically controlled due to weathering and fracturing activities of the underlying rocks typified of a basement complex environment. This view is believed to be the prevailing scenario in Nigerian basement complex terrain (Offodile 2014; Olabode 2019). Comparison of the water table elevation data with the topographical map indicates that the areas of lowest water table are representative of the main topographical highs. The topographical highs areas were regarded as the recharge areas, while the relatively plains/lowland areas with shallowest water table were regarded as the discharge areas. The shallow nature of the water table was believed to be influenced by pumping pattern and outcropping nature of the rocks. This also followed the results obtained by the work of Nwankwor et al. (1988). Groundwater divides in the

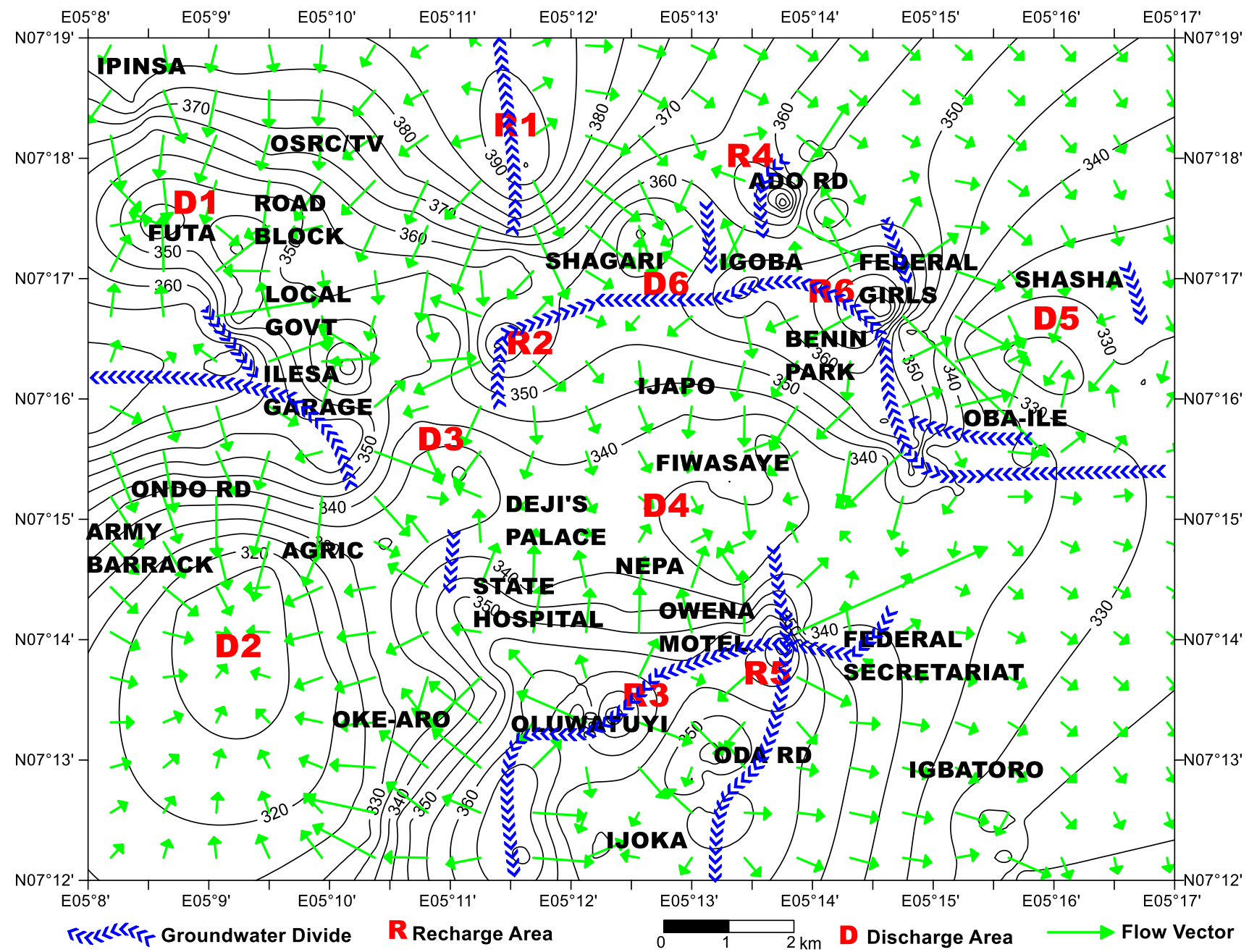

Fig. 3 Groundwater table heads distribution map showing flow vectors, recharge $(R)$ discharge $(D)$ areas and groundwater divides

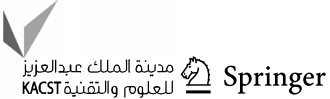


Table 1 Calculated pollution potential $(P)$ and its qualitative risk category $(\mathrm{QRC})$ for the recharge areas (RA)

\begin{tabular}{lllllllllll}
\hline Location & $D$ & $R$ & $A$ & $S$ & $T$ & $I$ & $C$ & $P$ & QRC & RA \# \\
\hline 1 & 45 & 24 & 12 & 18 & 9 & 15 & 3 & 126 & Moderate & R1 \\
2 & 35 & 24 & 12 & 18 & 9 & 15 & 3 & 116 & Low & R1 \\
3 & 35 & 24 & 12 & 18 & 9 & 15 & 3 & 116 & Low & R1 \\
4 & 45 & 24 & 12 & 18 & 5 & 15 & 3 & 122 & Moderate & R2 \\
5 & 45 & 24 & 12 & 18 & 3 & 15 & 3 & 120 & Moderate & R2 \\
6 & 45 & 24 & 12 & 18 & 9 & 15 & 3 & 126 & Moderate & R2 \\
7 & 45 & 24 & 12 & 4 & 3 & 15 & 3 & 106 & Low & R3 \\
8 & 35 & 24 & 12 & 4 & 9 & 15 & 3 & 102 & Low & R3 \\
9 & 45 & 24 & 12 & 4 & 9 & 15 & 3 & 112 & Low & R3 \\
10 & 45 & 24 & 12 & 18 & 5 & 15 & 3 & 122 & Moderate & R4 \\
11 & 45 & 24 & 12 & 18 & 5 & 15 & 3 & 122 & Moderate & R4 \\
12 & 35 & 24 & 12 & 18 & 5 & 15 & 3 & 112 & Low & R4 \\
13 & 45 & 24 & 12 & 18 & 5 & 15 & 3 & 122 & Moderate & R5 \\
14 & 45 & 24 & 12 & 18 & 9 & 15 & 6 & 129 & Moderate & R5 \\
15 & 45 & 24 & 12 & 18 & 3 & 15 & 3 & 120 & Moderate & R5 \\
16 & 45 & 24 & 12 & 18 & 5 & 15 & 3 & 122 & Moderate & R6 \\
17 & 45 & 24 & 12 & 18 & 9 & 15 & 3 & 126 & Moderate & R6 \\
18 & 45 & 24 & 12 & 18 & 9 & 15 & 6 & 129 & Moderate & R6 \\
\hline
\end{tabular}

Table 2 Calculated pollution potential $(P)$ and its qualitative risk category $(\mathrm{QRC})$ for the discharge areas (DA)

\begin{tabular}{lllllllllll}
\hline Location & $D$ & $R$ & \multicolumn{1}{l}{$A$} & \multicolumn{1}{l}{$S$} & \multicolumn{1}{l}{$T$} & \multicolumn{1}{l}{ I } & \multicolumn{1}{l}{$P$} & QRC & DA \# \\
\hline 1 & 45 & 24 & 12 & 4 & 3 & 15 & 3 & 106 & Low & D1 \\
2 & 35 & 24 & 12 & 4 & 9 & 15 & 3 & 102 & Low & D1 \\
3 & 25 & 24 & 12 & 4 & 3 & 15 & 3 & 86 & Low & D1 \\
4 & 45 & 24 & 12 & 18 & 10 & 15 & 3 & 127 & Moderate & D2 \\
5 & 45 & 24 & 12 & 18 & 10 & 15 & 3 & 127 & Moderate & D2 \\
6 & 35 & 24 & 12 & 18 & 9 & 15 & 3 & 116 & Low & D2 \\
7 & 45 & 24 & 12 & 18 & 5 & 15 & 3 & 122 & Moderate & D3 \\
8 & 35 & 24 & 12 & 18 & 5 & 15 & 3 & 112 & Low & D3 \\
9 & 45 & 24 & 12 & 18 & 9 & 15 & 3 & 126 & Moderate & D3 \\
10 & 50 & 24 & 12 & 18 & 5 & 15 & 3 & 127 & Moderate & D4 \\
11 & 45 & 24 & 12 & 18 & 9 & 15 & 3 & 126 & Moderate & D4 \\
12 & 35 & 24 & 12 & 18 & 9 & 15 & 3 & 116 & Low & D4 \\
13 & 35 & 24 & 12 & 18 & 9 & 15 & 3 & 116 & Low & D5 \\
14 & 45 & 24 & 12 & 18 & 9 & 15 & 3 & 126 & Moderate & D5 \\
15 & 45 & 24 & 12 & 18 & 9 & 15 & 3 & 126 & Moderate & D5 \\
16 & 50 & 24 & 12 & 18 & 5 & 15 & 3 & 127 & Moderate & D6 \\
17 & 25 & 24 & 12 & 18 & 5 & 15 & 3 & 102 & Low & D6 \\
18 & 45 & 24 & 12 & 18 & 5 & 15 & 3 & 122 & Moderate & D6 \\
\hline
\end{tabular}

study area were observed to occur along the boundaries of groundwater recharge and discharge areas. It actually separates areas where the water flows in opposite direction. Some divides were found to flow towards nearby surface water bodies (streams) following the prevailing elevation, pumping pattern, water usage and nearness to the delineated groundwater recharge and discharge areas of Akure area (Fig. 3).

\section{DRASTIC approach}

Summary of calculated values of DRASTIC Index/pollution potential for the recharge and discharge areas are presented in Tables 1 and 2. The result shows that weightage values assigned for the first hydrogeological parameter (depth to water table) ranges from 35 to 45 for the recharge areas and 25 to 50 in the discharge areas. This reveals the distinct variation in the depth to water table for Akure metropolis. 
It also submits that the water table depth ranges from shallow to moderately deep. The shallow aquifers are found at the plain areas and moderately deep aquifers found at the elevated areas. Fixed net recharge weightage value of 24 was assigned for all the wells representative of both recharge and discharge areas. The weightage value for Aquifer Media was fixed at 12 for both the recharge and discharge areas because the unconfined aquifers taps its water from the weathered layers above the basement rocks underlying Akure area. Variable weightage value of 4-18 was assigned for soil media representative of the recharge and discharge areas due to the variabilities and different soil classes observed in the area reflecting clay and sand content of the soils according to Smyth and Montgomery (1962) soil classification (a classification found relevant to Akure area). There is, however, variation in the weightage values obtained for the topography which is another hydrogeological parameter due to the ruggedness of Akure area. The weightage values range from 3 to 9 and 3 to 10 for the recharge and discharge areas, respectively. The impact of vadose zone weightage value for all the recharge and discharge areas was fixed at 15 since the materials within this zone comprises sand, silt and clay. The weightage value for hydraulic conductivity ranges from 3 to 6 in recharge areas and fixed at 3 for the discharge areas. The degree of weathering activities is responsible for the hydraulic conductivity influenced by permeable nature of material making up the unconfined aquifers in Akure area (Table 3).

The pollution potential (DRASTIC Index) was obtained for each of the wells in each recharge area. The Pollution Potentials were summed up for each of the six recharge areas (R1, R2, R3, R4, R5 and R6). The approach was also applied to all the six discharge areas (D1, D2, D3, D4, D5 and D6) and is presented in Tables 1 and 2 and Fig. 4. The results showed that the recharge areas have higher pollution potential values than the discharge areas with pollution potential values for recharge areas ranging from 102 to 129 with average value of 120 while the discharge areas ranges from 86 to 127 with average value of 117 . This indicates that groundwater sourced from recharge areas are possibly more pollution prone than that from discharge areas.

\section{Runoff approach}

The intense and growing development in every urban setting especially in Akure area has led to the construction of several civil engineering structures with consequent extensive and vast surface coverage such as buildings, roads, pavements, motor parks, etc. Activities prevailing in this area usually lead to the compaction and hardening of the land surfaces, thereby yielding low infiltration rate but supportive of high runoff rate. Soil type and sub soil conditions, land use type, type and intensity of vegetation and prevailing rainfall are among many factors that influence the runoff rate

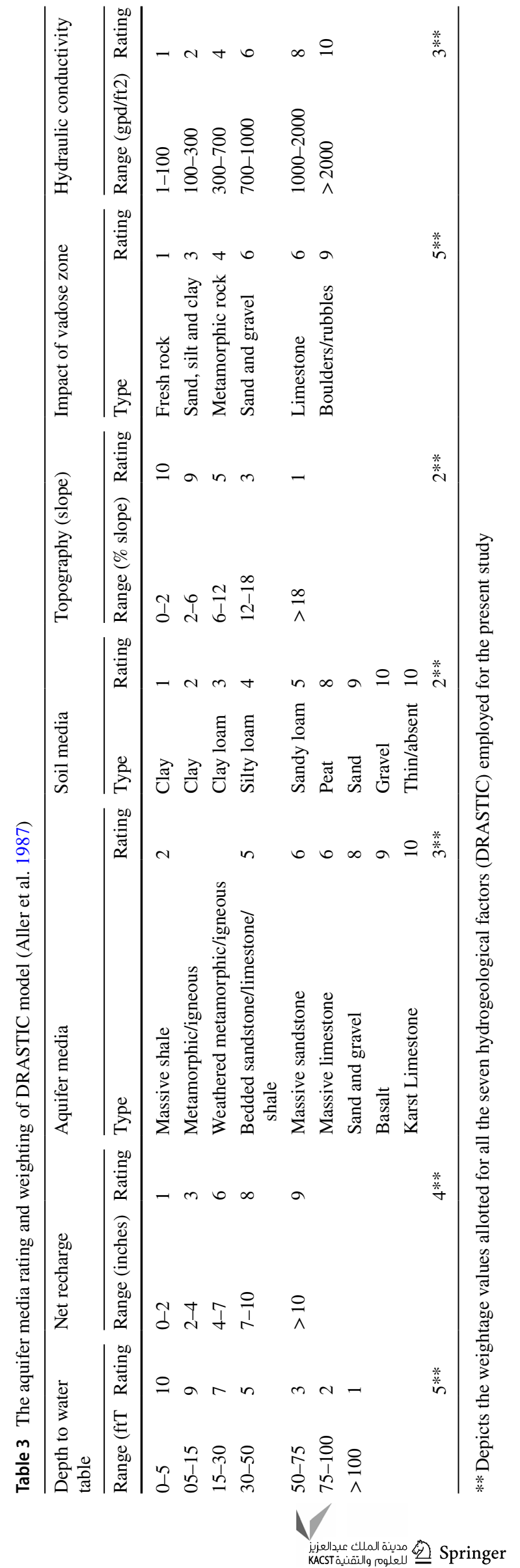




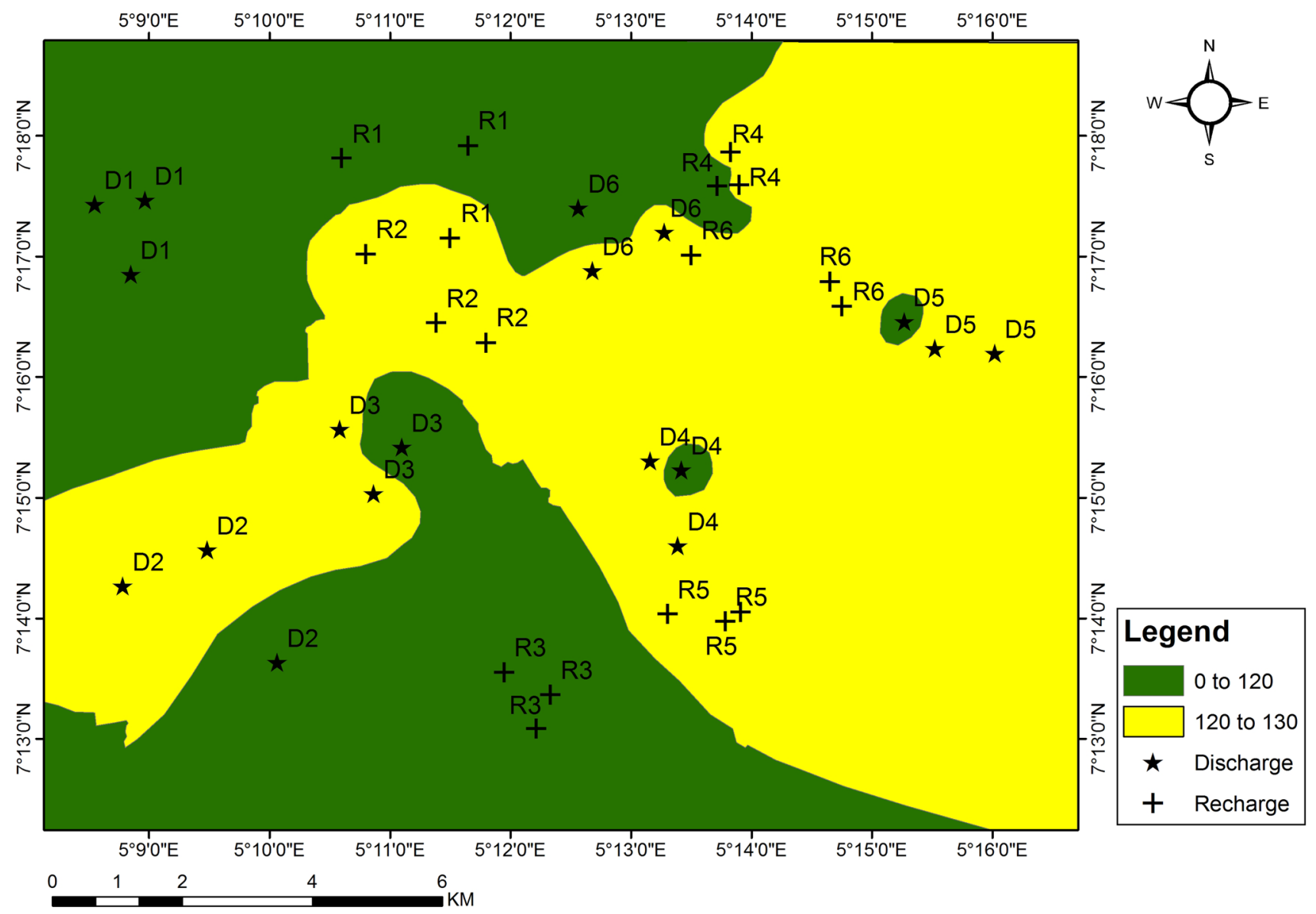

Fig. 4 Groundwater pollution potential map for the study area

(Offodile 2014; Fagbohun et al. 2017). Areas with runoff amount reaching 100 have been adjudged to be underlain by unfractured and totally impermeable lithological units and aided with high rainfall amount falling and reaching ultimately the surface water bodies. Areas with lower runoff amount or zero amount are underlain by highly permeable lithological units with not so much rain fall amount (Offodile 2014; Aladejana et al. 2016; Olabode 2019). High runoff observed in parts of Akure area is suggestive of the leading sources of water quality impairments on both groundwater and surface water. This impairment to the water quality in Akure area is due to the possible carriage of harmful substances during rain as runoff move from one area to another. The generated terrain-based map for Akure area shows that runoff ranges from 58 to 83 with the discharge areas possessing moderate runoff (Fig. 5). The recharge areas experience high runoff amount. Generally, areas delineated with moderate to high runoff in the study area were observed to be underlain with basement rocks such as charnockite and granite gneiss. These rocks are usually characterized by their low degree of weathering and fracturing. They are found to be impermeable thereby supportive of high runoff events. Areas with the fair to moderate runoff amount were underlain by granitic rocks. These rocks are usually weathered, thereby supporting appreciable amount of infiltrating water from the runoff water. It was also observed that wells in recharge areas were found in elevated areas with attendant high runoff amount indicating probable high pollution potential or threat. The less pollution potential or threat will be experienced in the discharge areas found in depressed areas due to their low runoff amount.

\section{Water quality}

Water quality index results range from 13.32 to 109.94 with mean value of 38.970 for discharge areas, while water quality index results range from 19.18 to 55.35 with mean value of 32.187 for recharge areas (Tables 4, 5; Fig. 6). WQI results were compared with the delineated recharge and discharge areas, and it was discovered that seventeen wells fall into good to very good water type except for a well which falls into poor water type. In discharge areas, thirteen wells fall within good to very good water type category with four and one wells falling into poor and unsuitable water type 


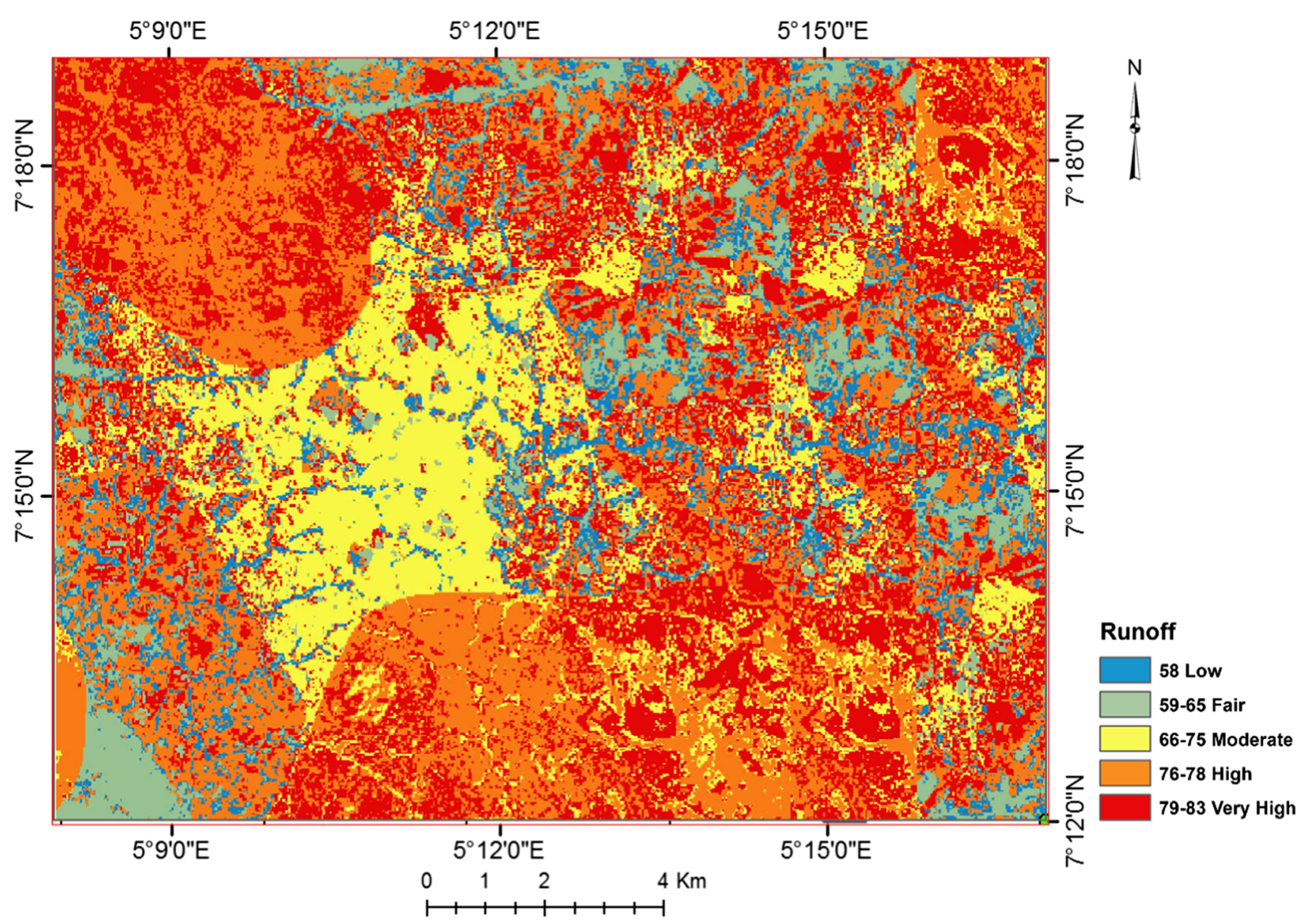

Fig. 5 Terrain-based runoff map of the study area

Table 4 Water quality index range and types of water

\begin{tabular}{llll}
\hline Range & Types of water & Recharge area & Discharge area \\
\hline$<25$ & Excellent/very good water & 5 & 5 \\
$26-50$ & Good water & 12 & 8 \\
$51-75$ & Poor water & 1 & 4 \\
$76-100$ & Very poor water & Nil & Nil \\
$>100$ & Water unsuitable for & Nil & 1 \\
& drinking purposes & & \\
\hline
\end{tabular}

categories, respectively. The chemical quality of the water samples from each of the identified recharge and discharge areas was all found to be within the acceptable limits of the World Health Organization (WHO 2011) standards for drinking and domestic purposes. The water quality index, however, disagrees with the results of the pollution potential and runoff amount.
Table 5 Various physico-chemical parameters for WQI

\begin{tabular}{lll}
\hline Parameters & Relative weight $(\mathrm{Wi})$ & $\begin{array}{l}\text { Standard } \\
\text { concentration } \\
(\mathrm{Si})\end{array}$ \\
\hline Calcium & 0.19802 & 75 \\
Magnesium & 0.29703 & 50 \\
Sodium & 0.07426 & 200 \\
Potassium & 0.14857 & 100 \\
Bicarbonate & 0.14851 & 100 \\
Sulphate & 0.07426 & 200 \\
Chloride & 0.05941 & 250 \\
\hline
\end{tabular}

\section{Hydrogeochemistry and evolution of Akure groundwater}

The trilinear plots (Piper diagram) (Fig. 7) show that the $\mathrm{Ca}-\mathrm{HCO}_{3}$ hydrochemical facies type dominated Akure area, a typical basement complex area. This water type is rich in alkaline earth cation (calcium) and weak acids (bicarbonates), thereby exceeding the alkalies and strong acids usually termed as alkaline waters. The water of this type 


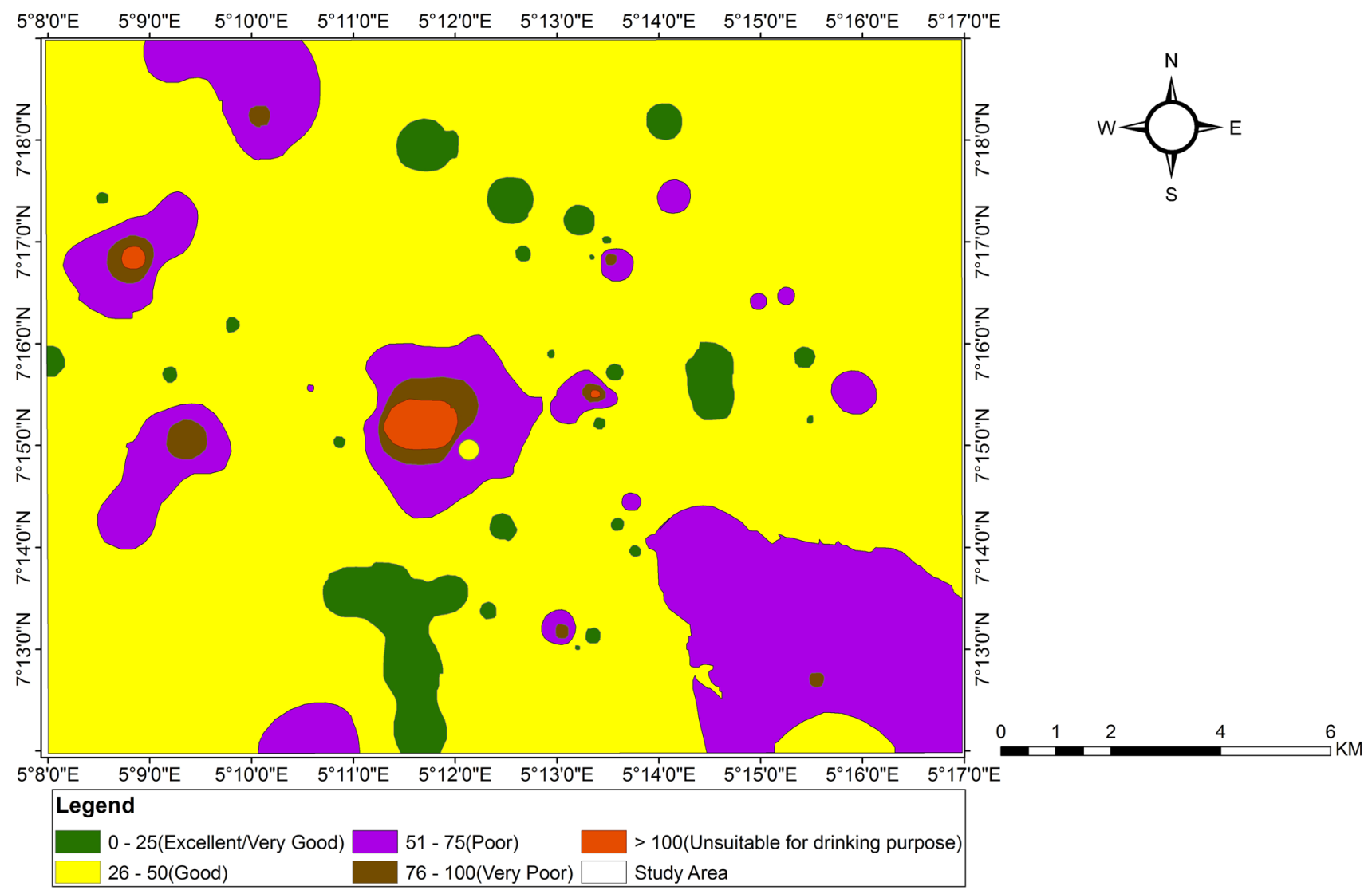

Fig. 6 Water quality index spatial distribution map for Akure area

is usually wholesome, natural and harmless for drinking purpose (Oyedele et al. 2019). The dominant anion $\left(\mathrm{HCO}_{3}\right)$ in the groundwater from recharge and discharge areas indicates carbonic acid silicate weathering of basement complex rocks as the probable source of bicarbonate in these water (Rogers 1989). All the sample representatives of recharge and discharge areas have $\mathrm{Na} / \mathrm{Cl}$ ratio less than 1 reflecting the prevalence of ion-exchange process acting in the Akure area (Elango et al. 2003). All the groundwater samples from recharge areas have positive Chloro Alkaline Indices values which suggest the presence of direct ion exchange of $\mathrm{Na}$ and $\mathrm{K}$ from water with magnesium and calcium in the aquifer material/rocks underlying Akure area (Bozdag 2016).

Three groundwater samples in the discharge areas have negative CAI values suggesting the presence of ion (cation-anion) exchange, and this exchange is indirect (Schoeller 1967; Marghade 2015). The remaining fifteen groundwater samples with positive indices value greater than zero suggest the presence of strong direct ion exchange of $\mathrm{Na}$ and $\mathrm{K}$ from water with magnesium and calcium in the aquifer material/rock underlying Akure area and also introducing addition of $\mathrm{Cl}$ in the groundwater of the study area (Schoeller 1967; Marghade 2015; Bozdag 2016).
Accurate Gibbs plots for recharge and discharge of Akure area were obtained by the plots of TDS against ionic ratios $\left(\mathrm{Na} /(\mathrm{Na}+\mathrm{Ca})\right.$ and $\mathrm{Cl} /\left(\mathrm{Cl}+\mathrm{HCO}_{3}\right)$. All the samples from the recharge and discharge areas fall both in the rock-water interaction dominance zones of the Gibbs diagram (Figs. 8a, b, 9a, b). The water-rock interaction dominance indicates that there is a strong interaction between the chemistry of the underlying rock lithologies and the chemistry of the groundwater. This was induced by intense weathering activities aided with long resident time spent by the water in the voids of the aquifer media. The contribution of precipitation in the waters of the study area, a typical rainforest environment, can not also be jettisoned. The conjunctive source of water from precipitation and chemical weathering activities in the subsurface media will aid high infiltration into the aquifer which will bring about projected increase in amount of recharge water to the unconfined aquifers in Akure. The plots also align in agreement with previous works carried out in similar geological environment and climate as the study area, a typical basement complex, which usually experience dominant activities of rock weathering, leading to the creation of the storage point for groundwater. The possibility that precipitation-weathering process has led to the increase 
Fig. 7 Trilinear Piper diagram plots of dissolved ions

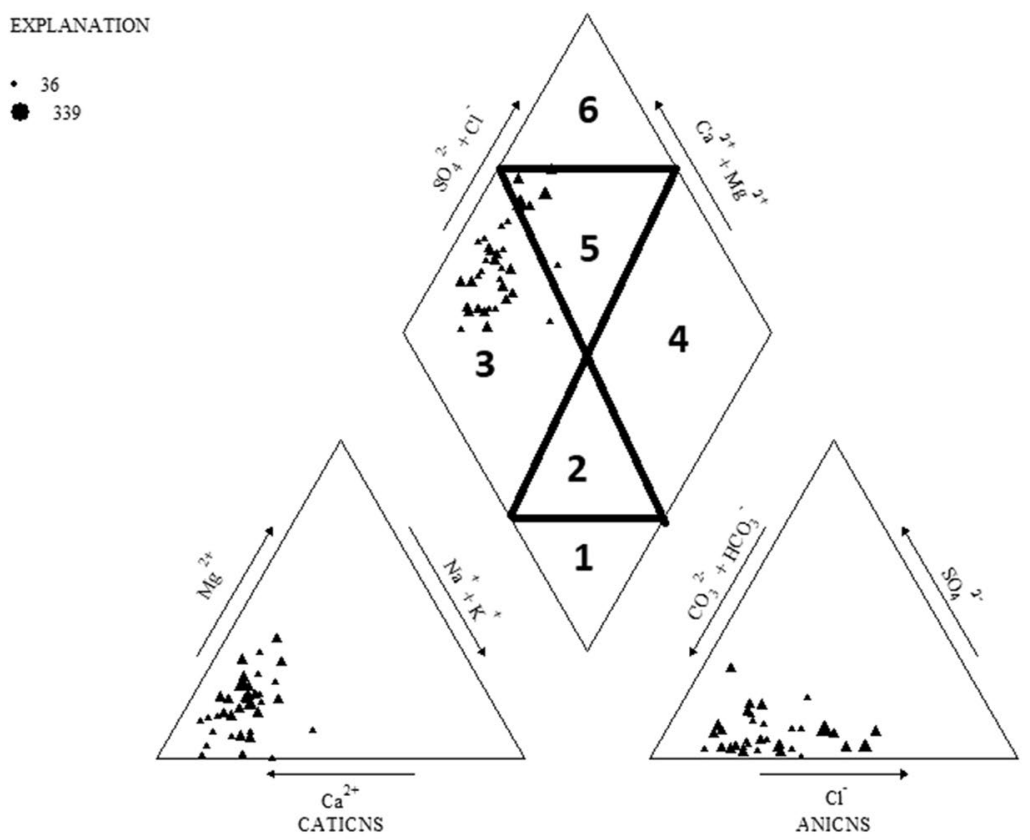

Key

1-Na-HCO ${ }_{3}$ type; 2 - Mixed $\mathrm{Ca}-\mathrm{Na}-\mathrm{HCO}_{3}$ type; $3-\mathrm{Ca}-\mathrm{HCO}_{3}$ type; 4-Na-Cl type; 5-Mixed Ca-Mg-Cl type; 6-Ca-Cl type

in concentrations of all ionic species in the groundwaters from the recharge and discharge areas cannot be ruled out at all. No sample falls within the evaporation and precipitation dominance which presumed that the aquifer materials were made of highly permeable materials.

\section{Descriptive analysis}

The standard deviation values of EC (93 and 171) are the highest from the recharge and discharge areas (Tables 6, 7). The standard deviation of EC is lower in the recharge areas than the discharge areas, with their means values of $182 \mu \mathrm{s} /$ $\mathrm{cm}, 260 \mu \mathrm{s} / \mathrm{cm}, 93 \mu \mathrm{s} / \mathrm{cm}$ and $171 \mu \mathrm{s} / \mathrm{cm}$. These values are in accordance with the water quality index result. Due to this observed high standard deviations in its concentrations, the result submits that its major contribution in the classification of the water type is related to its ionic strength. This is found to be responsible for the dissolution of all the other dissolved ions present in the waters.

\section{Correlation matrix}

Statistical analysis was performed on the data of physicochemical parameters and major ion concentration to detect the relationship and differences between the groundwater samples. The average value of all the variables $(\mathrm{Ca}, \mathrm{Mg}$, $\mathrm{Na}, \mathrm{K}, \mathrm{HCO}_{3}, \mathrm{SO}_{4}, \mathrm{Cl}$, TDS, EC) was determined and is tabulated as matrix $(9 \times 16)$ in Tables 8 and 9 .
For the recharge areas, electrical conductivity shows strong to very strong correlation with $\mathrm{Na}(0.7), \mathrm{Cl}(0.7)$ and TDS (0.9) which means that conductivity increases with dissolution of ions through ion-exchange reaction in the unconfined aquifer groundwater system of Akure area (Subba Rao 2002). The correlation evident between $\mathrm{Na}$ with $\mathrm{Cl}$ (0.7), $\mathrm{Mg}(0.6)$, TDS (0.7), and EC (0.7) suggests high mobility of ions aided with strong ionic strength. There is also strong positive correlation between $\mathrm{Na}$ and $\mathrm{Mg}$ (0.6), $\mathrm{Ca}$ and $\mathrm{Cl}$ (0.66) associated with anthropogenic activities, a characteristic of any urban setting. $\mathrm{Na}$ and $\mathrm{Cl}$ (0.7), Na and TDS (0.7), Na and EC (0.7), Cl-TDS (0.7) support the effectiveness in the mineralization and salinization of the groundwater in Akure, Cl-EC (0.7) and TDSEC (0.9). The good positive correlations of $\mathrm{Na}-\mathrm{Cl}(0.7)$ infer progressive reaction with feldspars from the minerals and groundwater in the unconfined aquifer system. The contribution of anthropogenic activities is also a major factor in an urban metropolis like Akure area thereby supportive of pollution.

For the discharge areas, electrical conductivity shows strong and very strong correlation with $\mathrm{Na}(0.8), \mathrm{Cl}(0.7)$ and TDS (0.9); moderate correlation with $\mathrm{Mg}(0.5)$, which means that conductivity increases with dissolution of ions via ion-exchange or oxidation-reduction reaction in the unconfined aquifer groundwater system (Subba Rao 2002; Jeyaraj et al. 2006). The strong to very strong correlation evident between $\mathrm{Na}$ with $\mathrm{Cl}(0.7)$, TDS (0.8) and EC (0.8) and moderate correlation with $\mathrm{Mg}(0.5)$ and $\mathrm{Ca}(0.5)$ suggest

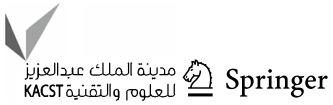



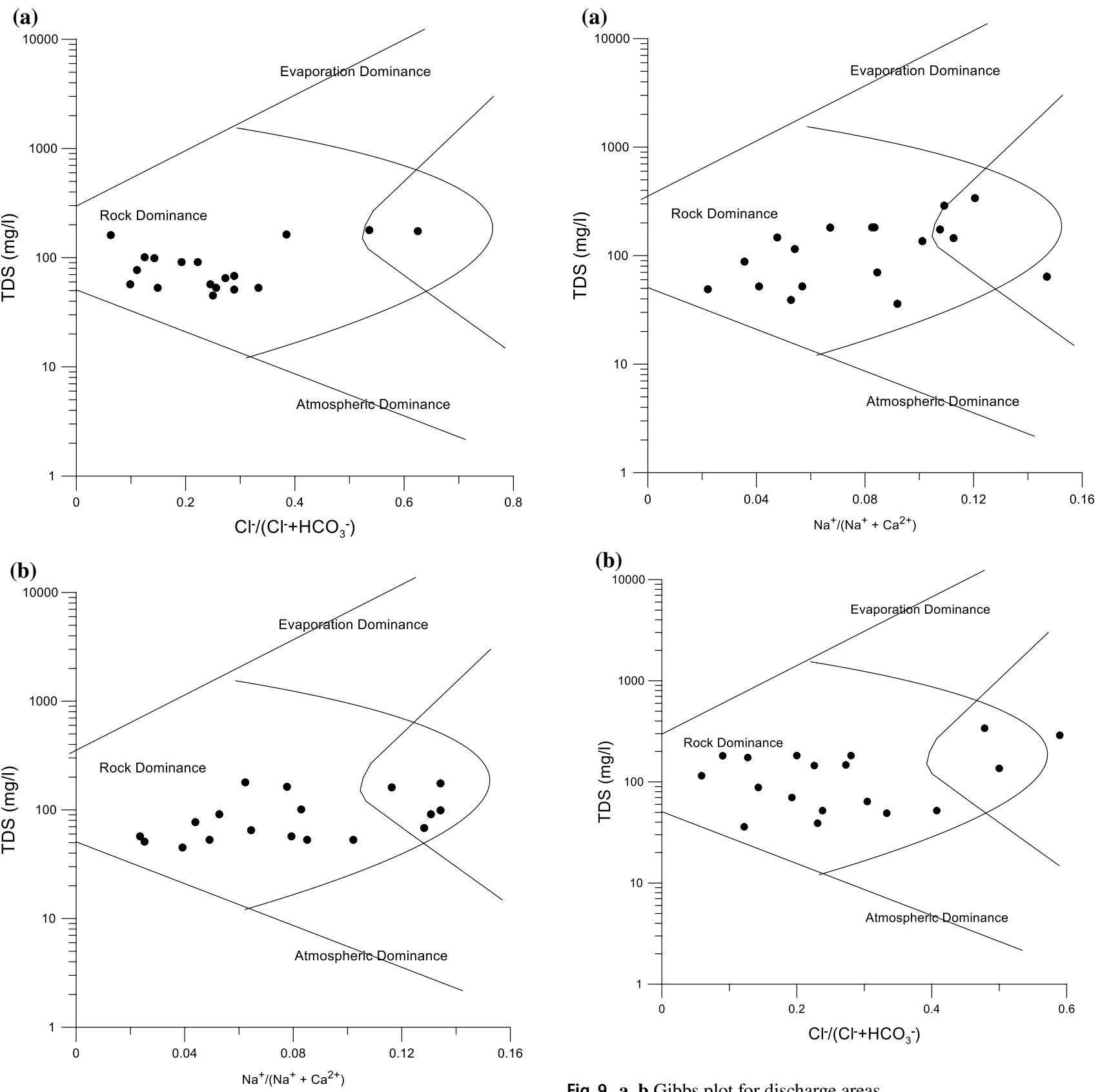

Fig. 9 a, b Gibbs plot for discharge areas

Fig. 8 a, b Gibbs plot for recharge areas

high mobility of ions aided with strong ionic strength. There is also significant positive strong correlation between $\mathrm{Na}$ and $\mathrm{Mg}$ (0.5), $\mathrm{Ca}$ and $\mathrm{Mg}$ (0.6) raising possible ion-exchange process but however masked by anthropogenic inputs from domestic and industrial wastes. $\mathrm{Mg}$ and $\mathrm{Na}(0.5), \mathrm{Mg}$ and $\mathrm{HCO}_{3}(0.7), \mathrm{Mg}$ and TDS (0.5), $\mathrm{Mg}$ and EC (0.5), Na and $\mathrm{Cl}(0.7)$, and $\mathrm{Na}$ and TDS (0.85) support the effectiveness in the mineralization and salinization of the groundwater in Akure. Strong to very strong correlation between the following variables: $\mathrm{Na}$ and $\mathrm{EC}(0.8), \mathrm{Cl}$ and TDS (0.7) were

observed which support the effectiveness in the mineralization and salinization of groundwater in Akure. The correlation between $\mathrm{Cl}$ and $\mathrm{EC}(0.7)$, and TDS and EC (0.9) indicates the presence of anthropogenic input through leaching of pollutants into the groundwater. The good positive correlations of $\mathrm{Na}-\mathrm{Cl}(0.7)$ also imply progressive reaction with feldspars in the aquifer system in the form of pollution.

\section{Principal component analysis}

The results of the principal component analysis are presented as Tables 10 and 11. Scree plots are presented in 


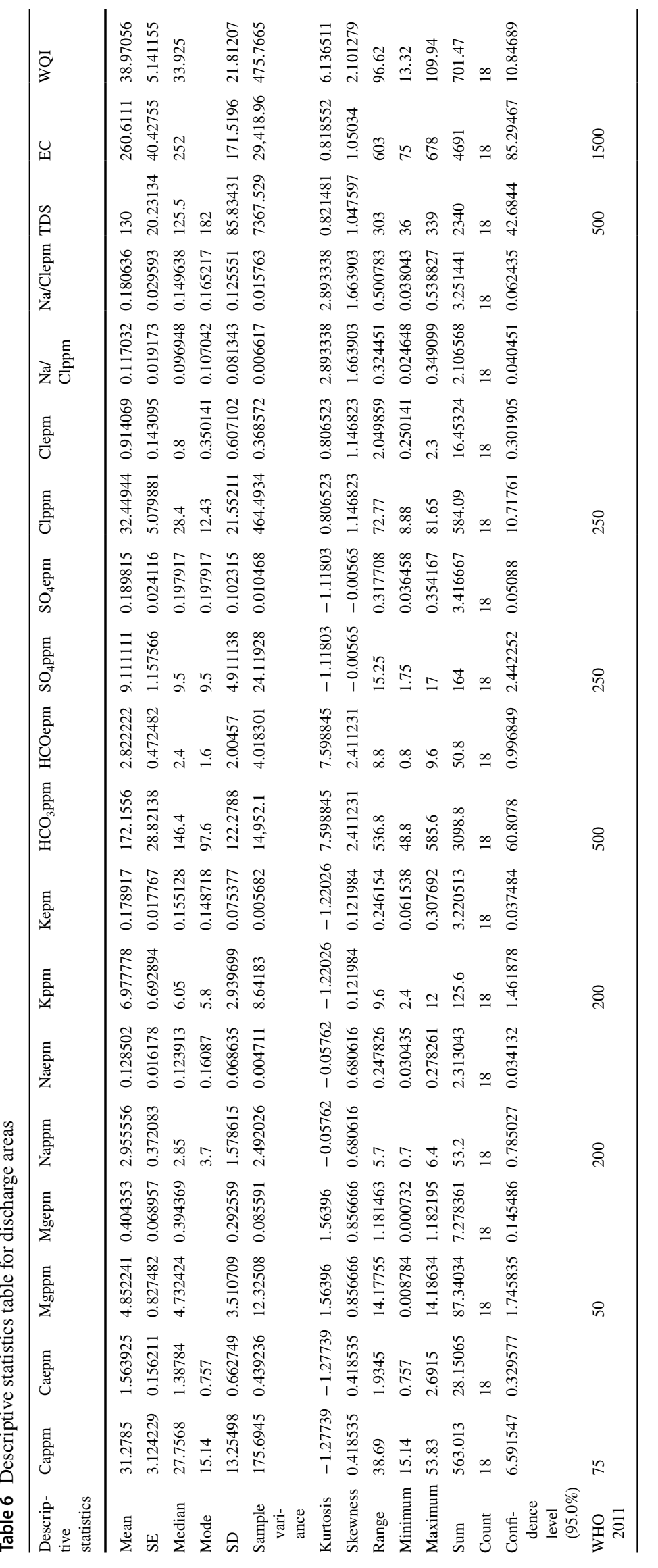




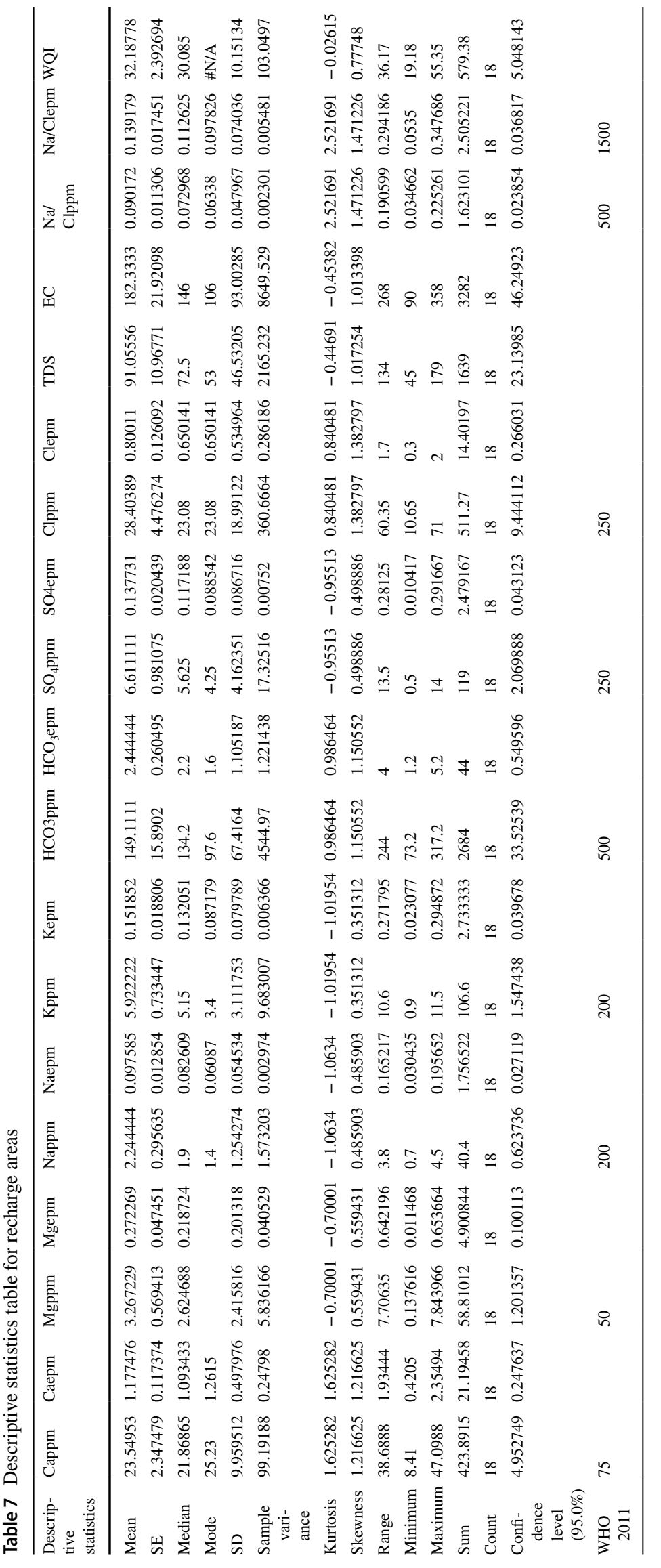


Table 8 Correlation table for recharge areas

\begin{tabular}{|c|c|c|c|c|c|c|c|c|c|}
\hline & Cappm & Mgppm & Nappm & Kppm & $\mathrm{HCO}_{3} \mathrm{ppm}$ & $\mathrm{SO}_{4} \mathrm{ppm}$ & Clppm & TDS & $\mathrm{EC}$ \\
\hline Cappm & 1 & & & & & & & & \\
\hline Mgppm & 0.340432 & 1 & & & & & & & \\
\hline Nappm & 0.470463 & $0.64037 *$ & 1 & & & & & & \\
\hline Kppm & -0.21899 & 0.063317 & -0.15565 & 1 & & & & & \\
\hline $\mathrm{HCO}_{3} \mathrm{ppm}$ & -0.19063 & 0.060695 & -0.03715 & -0.03246 & 1 & & & & \\
\hline $\mathrm{SO}_{4} \mathrm{ppm}$ & -0.05974 & 0.066774 & 0.167726 & -0.43937 & -0.05868 & 1 & & & \\
\hline Clppm & $0.660213^{*}$ & 0.405971 & $0.728494 *$ & -0.47386 & -0.22483 & 0.130133 & 1 & & \\
\hline TDS & 0.471585 & 0.411509 & $0.7352 * *$ & -0.34162 & 0.268979 & 0.206262 & $0.717752 *$ & 1 & \\
\hline $\mathrm{EC}$ & 0.469653 & 0.411559 & $0.734939^{*}$ & -0.33819 & 0.268597 & 0.203747 & $0.715681 *$ & $0.999962 * *$ & 1 \\
\hline
\end{tabular}

*Depicts strong connection, **depicts very strong connection

Table 9 Correlation table for discharge areas

\begin{tabular}{|c|c|c|c|c|c|c|c|c|c|}
\hline & Cappm & Mgppm & Nappm & Kppm & HCO3ppm & SO4ppm & Clppm & TDS & EC \\
\hline Cappm & 1 & & & & & & & & \\
\hline Mgppm & $0.654648^{*}$ & 1 & & & & & & & \\
\hline Nappm & $0.594448^{*}$ & $0.551947^{*}$ & 1 & & & & & & \\
\hline Kppm & 0.236889 & 0.011256 & 0.304752 & 1 & & & & & \\
\hline $\mathrm{HCO}_{3} \mathrm{ppm}$ & 0.452545 & $0.78324 *$ & 0.179527 & -0.09614 & 1 & & & & \\
\hline $\mathrm{SO}_{4} \mathrm{ppm}$ & -0.26963 & 0.057213 & -0.05528 & -0.26853 & -0.00744 & 1 & & & \\
\hline Clppm & 0.470332 & 0.339628 & $0.735713^{*}$ & 0.16907 & 0.024993 & -0.08168 & 1 & & \\
\hline TDS & 0.456492 & $0.520376^{*}$ & $0.845934 * *$ & 0.196197 & 0.141537 & 0.156079 & $0.724049 *$ & 1 & \\
\hline $\mathrm{EC}$ & 0.455868 & $0.521194 *$ & $0.84645^{* *}$ & 0.194716 & 0.141139 & 0.155047 & $0.724252 *$ & $0.999986^{* *}$ & 1 \\
\hline
\end{tabular}

*Depicts strong connection, **depicts very strong connection

Figs. 10 and 11. They include the loading for the rotated component matrix, eigenvalues for each component, and the percent and cumulative percent of variance explained by each component and communality, indicating the proportion of variance of each variable controlled by the set of components. From Tables 10 and 11, three principal components were extracted with eigenvalue more than 1 which together account for recharge and discharge areas are $77.151 \%$ and $82.173 \%$ of the total variance in the dataset, in which the first principal component, second principal component and third principal component for recharge and discharge areas are $46.881 \%$ and $15.560 \%, 14.710 \%$ and $48.722 \%, 18.000 \%$ and $15.451 \%$, respectively. The communalities of all the chemical variables range from 0.541 to 0.920 , and 0.563 to 0.947 for recharge and discharge areas indicating different contributions in the changing quality of groundwater in Akure (Marghade 2015). However, all the variables have their communalities greater than 0.50 .

\section{Principal component analysis for recharge areas}

$\mathrm{Na}, \mathrm{Cl}$, TDS and EC have high loading factor $(0.863$, $0.881,0.915$ and 0.913 ) and moderate positive loading of $\mathrm{Ca}(0.657), \mathrm{Mg}(0.584)$ on the principal component 1 according to Marghade 2015 classification of principal component (Table 10). The positive PC loadings are usually used to understand the relative contribution of the chemical variables on the groundwater quality (Marghade 2015). The combinations of high loading factor for the following dissolved $\mathrm{Ca}, \mathrm{Mg}, \mathrm{Na}, \mathrm{Cl}$ ions and $\mathrm{EC}$, observed on the first principal component (Table 10), suggest association of various hydrogeochemical processes responsible to enrichment of more mineralized water (TDS) but masked by anthropogenic urban activities. The moderate loading of $\mathrm{Ca}(0.657)$ suggests the release of this cation from the chemical weathering of rocks containing the following minerals; feldspar, pyroxene, mica and clay minerals in these rocks (granitic gneisses, charnockites and granites). The high loading factor of $\mathrm{Na}(0.863)$ and $\mathrm{Cl}(0.881)$ suggest non-lithological origin (absence of sedimentary rocks in basement complex area), but connected to culturally influenced shallow water overflow or unwanted causes typical of an urban area (Lawrence and Upchurch 1982). This, however, gives a picture of the rate at which the wells are being recharged and the degree of weathering of the aquifer medium. $\mathrm{Na}$ and $\mathrm{Cl}$ have the highest loading in 
Table 10 Principal component analysis result for recharge areas (3 components extracted)
Table 11 Principal component analysis result for discharge areas (3 components extracted)

\begin{tabular}{llllll}
\hline Chemical parameters & I & II & III & Communality & Initial \\
\hline $\mathrm{Ca}$ & $0.657^{* *}$ & 0 & -0.375 & 0.64 & 1 \\
$\mathrm{Mg}$ & $0.584^{*}$ & 0.435 & 0 & 0.541 & 1 \\
$\mathrm{Na}$ & $0.863^{* * *}$ & 0 & 0 & 0.791 & 1 \\
$\mathrm{~K}$ & -0.433 & $0.74 * *$ & 0 & 0.766 & 1 \\
$\mathrm{HCO}_{3}$ & 0 & 0 & $0.933^{* * * *}$ & 0.886 & 1 \\
$\mathrm{SO}_{4}$ & 0 & -0.728 & 0 & 0.602 & 1 \\
$\mathrm{Cl}$ & $0.881^{* *}$ & 0 & -0.321 & 0.879 & 1 \\
$\mathrm{TDS}$ & $0.915^{* * * *}$ & 0 & 0 & 0.92 & 1 \\
EC & $0.913^{* * * *}$ & 0 & 0 & 0.918 & 1 \\
$\%$ Total variance & 46.881 & 15.56 & 14.71 & & \\
$\%$ Cumulative & 46.881 & 62.44 & 77.151 & & \\
Eigenvalues & 4.219 & 1.4 & 1.324 & & \\
\hline
\end{tabular}

*Depicts low positive, $* *$ depicts medium positive, $* * *$ depicts high positive, $* * * *$ very high positive

\begin{tabular}{llllll}
\hline Chemical parameters & I & II & III & Communality & Initial \\
\hline $\mathrm{Ca}$ & $0.728^{* *}$ & 0.309 & -0.37 & 0.763 & 1 \\
$\mathrm{Mg}$ & $0.738^{* *}$ & $0.609^{* *}$ & 0 & 0.919 & 1 \\
$\mathrm{Na}$ & $0.916^{* * * *}$ & 0 & 0 & 0.878 & 1 \\
$\mathrm{~K}$ & 0 & -0.356 & -0.603 & 0.563 & 1 \\
$\mathrm{HCO}_{3}$ & 0.39 & $0.86^{* * *}$ & 0 & 0.893 & 1 \\
$\mathrm{SO}_{4}$ & 0 & 0 & $0.876^{* * *}$ & 0.768 & 1 \\
$\mathrm{Cl}$ & $0.779^{* * *}$ & -0.336 & 0 & 0.719 & 1 \\
$\mathrm{TDS}$ & $0.906^{* * * *}$ & 0 & 0 & 0.947 & 1 \\
$\mathrm{EC}$ & $0.906^{* * * *}$ & 0 & 0 & 0.947 & 1 \\
$\%$ Total variance & 48.722 & 18 & 15.451 & & \\
$\%$ Cumulative & 48.722 & 66.722 & 82.173 & & \\
Eigenvalues & 4.385 & 1.62 & 1.391 & & \\
\hline
\end{tabular}

*Depicts low positive, $* *$ depicts medium positive, $* * *$ depicts high positive, $* * * *$ very high positive terms of ions, which indicate their contribution among the water quality parameters, raising the pollution concern in waters of Akure area.

On the second principal component (PC2), the component is cation dominated of $\mathrm{K}$ which have high-positive loading of (0.740). The high loading of $\mathrm{K}$ could be traced to the dissolved minerals such as feldspars (orthoclase and microcline), micas and clay minerals released from the weathering of the host rocks (granitic gneisses, charnockites, and granites).

On the third principal component (PC3), only $\mathrm{HCO}_{3}$ have high-positive loading of (0.933). The strong loading of $\mathrm{HCO}_{3}$ is attributed to the reaction of feldspar minerals with carbonic acid in the presence of water (Elango et al. 2003). Meanwhile, the deficiency of sulphate ions in all the three principal components suggests that the waters have more cations of $\mathrm{Mg}$ and $\mathrm{Ca}$ in the groundwater (Khan 2015).

\section{Principal component analysis for discharge areas}

$\mathrm{Ca}, \mathrm{Mg}, \mathrm{Na}, \mathrm{Cl}$, TDS and EC have high loading factor $(0.728,0.738,0.916,0.779,0.906$ and 0.906$)$ on the principal component 1 . The combinations of $\mathrm{Ca}, \mathrm{Mg}, \mathrm{Na}$, $\mathrm{Cl}$ ions and $\mathrm{EC}$, influencing the high-positive loadings observed on the first principal component (Table 11), suggest that the first principal component is associated with similar hydrogeochemical processes as explained for the recharge areas responsible for the enrichment of more mineralized water (TDS) through ionic strength processes though masked by anthropogenic activities. The high loading factor of $\mathrm{Na}(0.916)$ and $\mathrm{Cl}(0.779)$ also suggests nonlithological origin (absence of sedimentary in the basement complex), but associated with culturally influenced surface runoff or waste sources typical of an urban area (Lawrence and Upchurch 1982). The very high positive loading could have resulted from the formation of clay products from the weathering of the underlying rocks. 
Fig. 10 Scree plot for recharge area

Fig. 11 Scree plot for discharge area

This was aided by their slow nature of drainage conditions (Hem 1991). This, however, gives a picture about the rate at which the wells are being recharged and degree of weathering of the aquifer medium. $\mathrm{Na}$ and $\mathrm{Cl}$ have the highest loading in terms of ions, which indicate their contribution among the quality parameters, which control the pollution in Akure area.
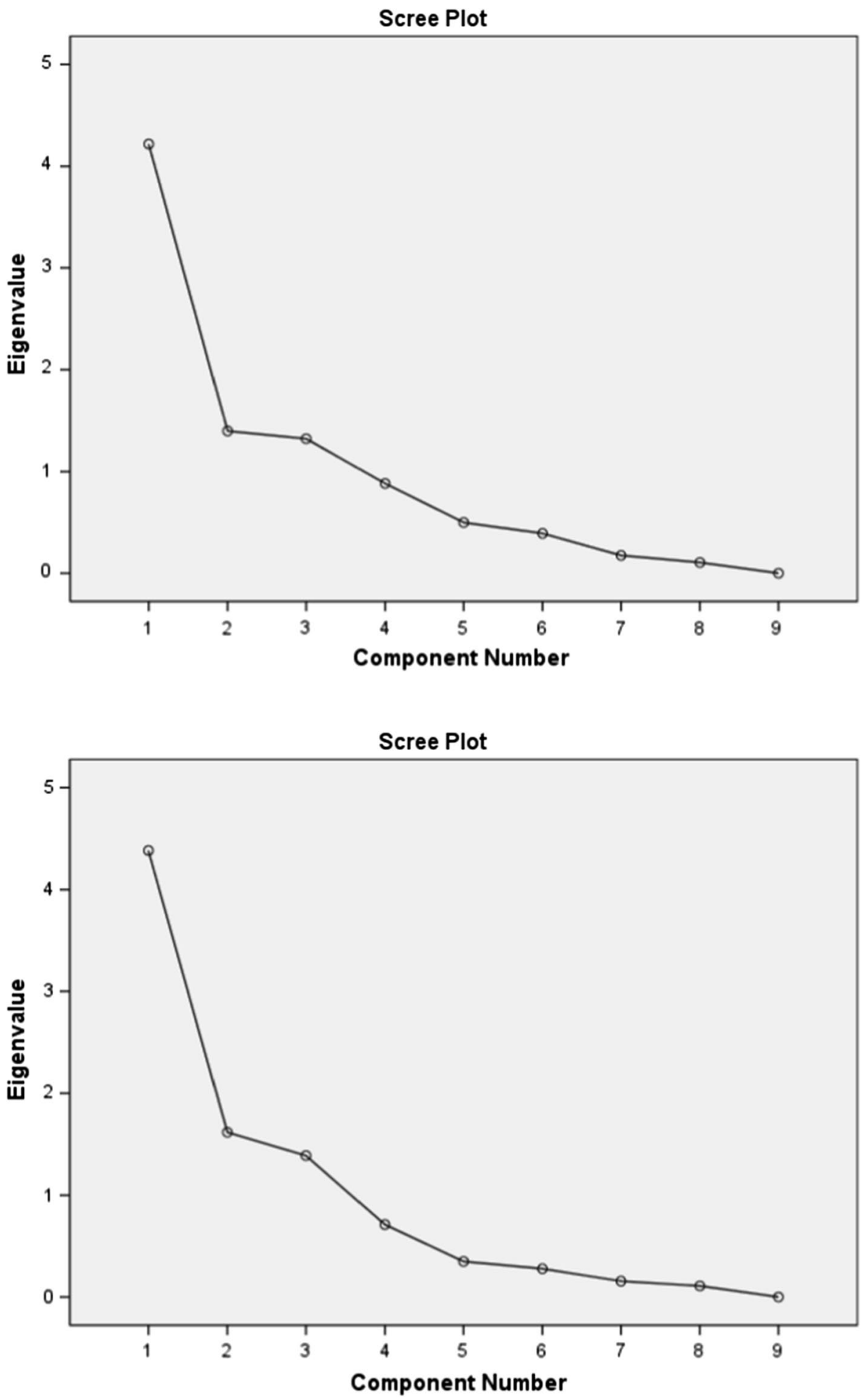

On the second principal component, only $\mathrm{HCO}_{3}$ have high-positive loading of (0.860) and moderate positive loading of $\mathrm{Mg}(0.609)$. The strong loading of $\mathrm{HCO}_{3}$ is attributed to the reaction of feldspar minerals with carbonic acid in the presence of water (Elango et al. 2003). It also indicates the strong interaction of infiltrating recharging water (precipitating water), with the soil and/lithology. During recharge, 
water absorbs large amount of $\mathrm{CO}_{2}$, released from the soil due to the decay of organic matter, root respiration, etc., and converts into $\mathrm{HCO}_{3}$ during weathering reactions (Jacks 1973; Berner and Berner 1987). The magnesium ions are attributed to the weathering of the minerals such as amphiboles, olivine, pyroxene and clay minerals which are the major constituents of the host rocks.

On the third principal component, only sulphates have high-positive loading of (0.876) which signifies the depletion of cations in the groundwater.

For Q-mode hierarchical analysis, ward linkage method revealed the results of parameters and are presented in two groups each for the recharge and discharge areas in Figs. 12 and 13 .

For the recharge areas, fifteen samples from recharge areas classified in Group 1 show good correlation with the concentration of $\mathrm{K}, \mathrm{HCO}_{3}, \mathrm{Cl}$, TDS, EC and $\mathrm{SO}_{4}$, while Group II comprises three samples displaying good correlation of concentration of $\mathrm{Ca}, \mathrm{Cl}$, TDS and EC.

For the discharge areas, ten samples from discharge areas classified in Group 1 show good correlation with the concentration of $\mathrm{Mg}, \mathrm{Cl}, \mathrm{HCO}_{3}$ and $\mathrm{SO}_{4}$, while Group II comprises eight samples displaying good correlation of high concentration of $\mathrm{Ca}, \mathrm{Na} \mathrm{Mg}, \mathrm{HCO}_{3}$, TDS and EC.

\section{Conclusion}

Recharge and discharge areas of a growing urban area like Akure area have been delineated with the aid of elevation and well data. The quality of groundwater in these areas falls within the acceptable limits of the World Health Organization (WHO) standards for domestic purpose. The $\mathrm{Ca}-\mathrm{HCO}_{3}$ hydrochemical facies type dominates the association of ions present in the samples which was believed to be consequent of the conjunctive activities of the intense weathering (rock-water and silicate weathering) and precipitation prevailing in Akure area. These activities contributed to the increasing concentrations of dissolved ions in the recharge and discharge areas as observed from the correlation and multivariate statistical studies. The results also showed that recharge areas have higher pollution potential values and runoff amount than the discharge areas, which indicates that groundwater in recharge areas is more susceptible to pollution than that in discharge areas. Among many factors or sources that are responsible for the high pollution potential in the recharge areas, critical ones include appreciable dissolved ions in the waters, high degree of weathering and anthropogenic activities which were not the case in the discharge areas making it less prone to pollution. This study has revealed
Fig. 12 Dendrogram for recharge area

\section{Dendrogram using Ward Linkage}

\section{Rescaled Distance Cluster Combine}

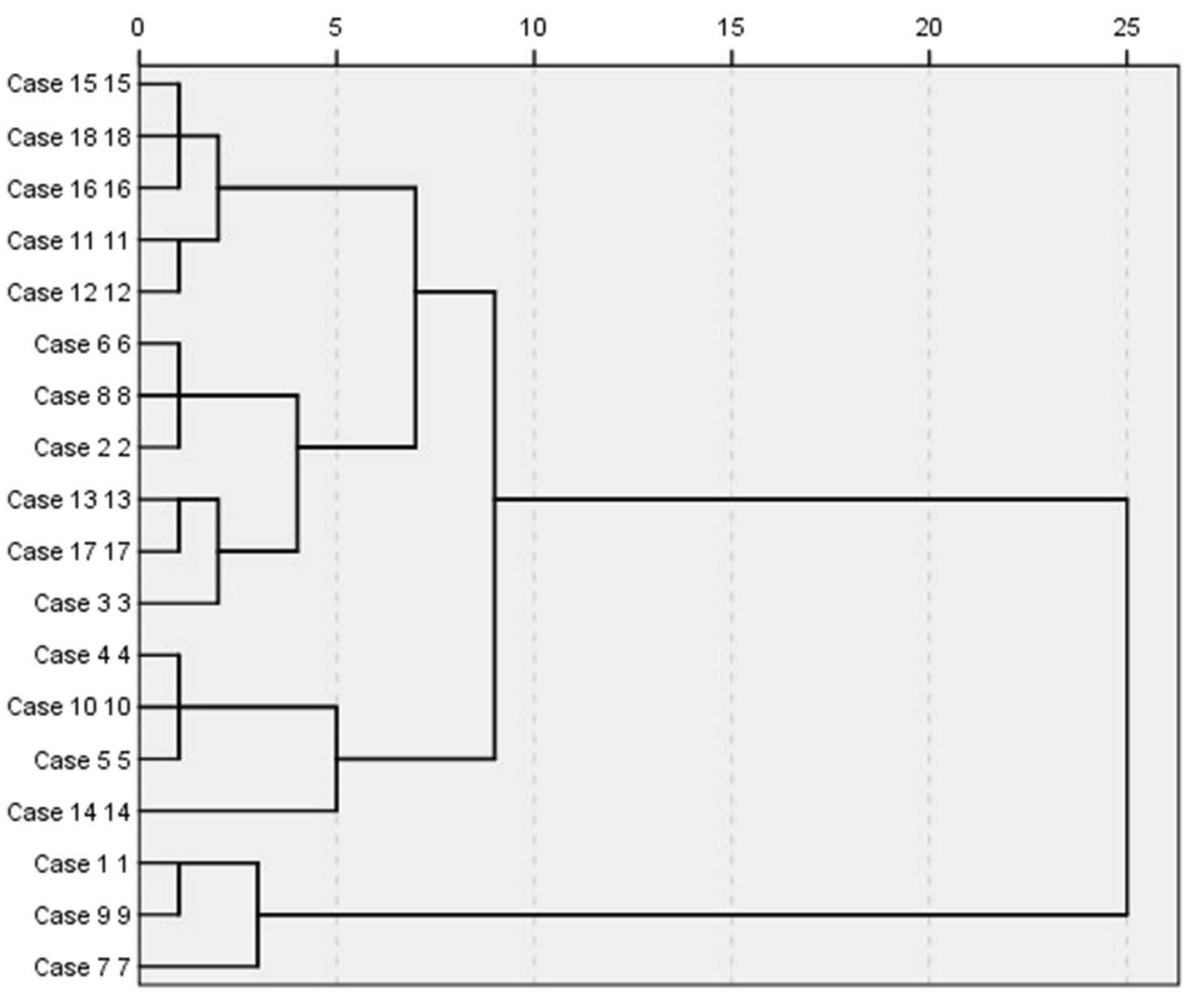


Fig. 13 Dendrogram for discharge area
Dendrogram using Ward Linkage

Rescaled Distance Cluster Combine

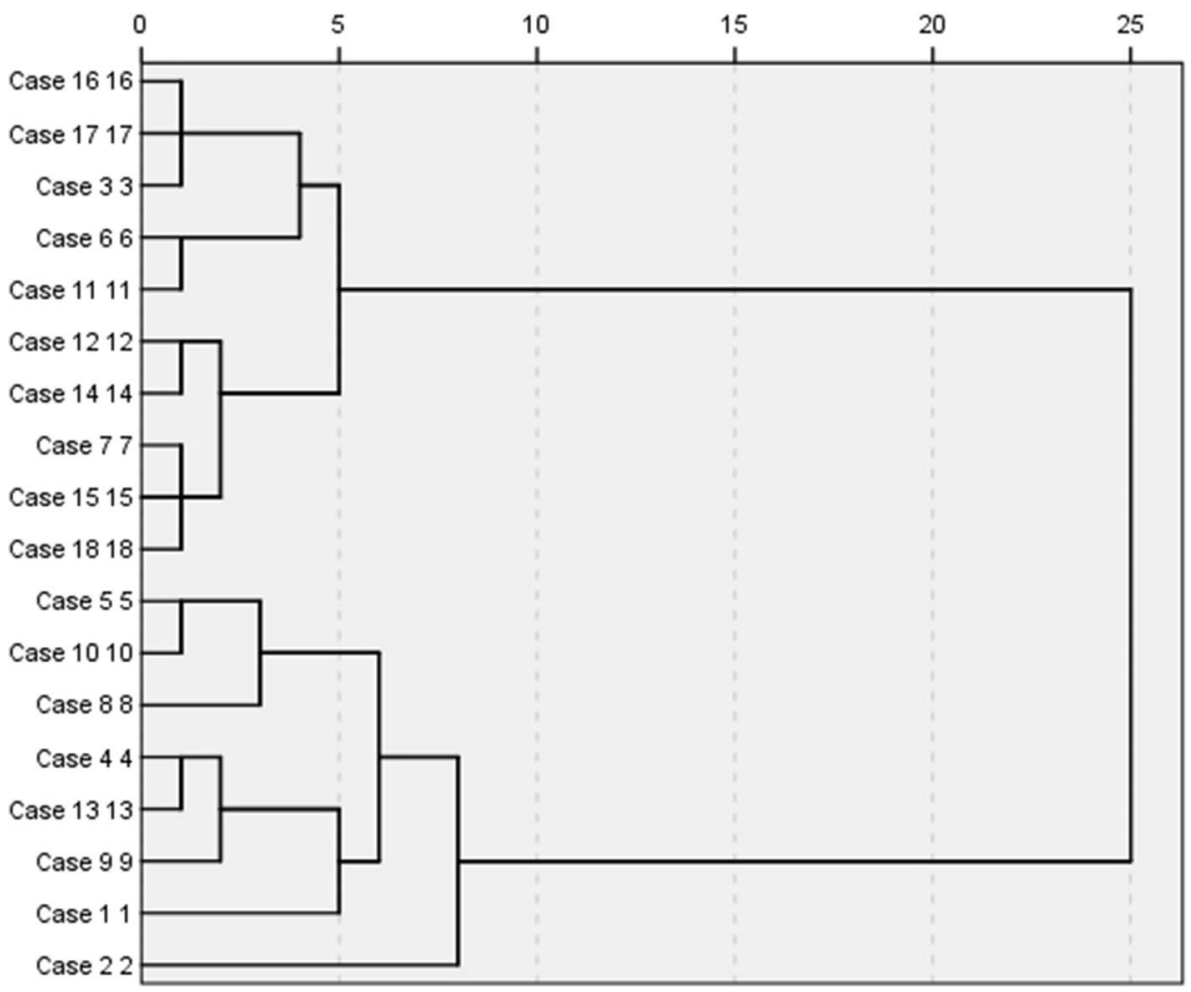

the present state of the quality of water representative of recharge and discharge areas and provided insights into the probable causes of pollution in this area. Areas prone to pollution should be checked by quick reduction and decentralizing of urban activities, and also formulation and enforcement of the best urban planning policies should be adopted by the local government authorities.

\section{Compliance with ethical standards}

Conflict of interest The authors declare that there is no conflict of interest in this manuscript.

Open Access This article is licensed under a Creative Commons Attribution 4.0 International License, which permits use, sharing, adaptation, distribution and reproduction in any medium or format, as long as you give appropriate credit to the original author(s) and the source, provide a link to the Creative Commons licence, and indicate if changes were made. The images or other third party material in this article are included in the article's Creative Commons licence, unless indicated otherwise in a credit line to the material. If material is not included in the article's Creative Commons licence and your intended use is not permitted by statutory regulation or exceeds the permitted use, you will need to obtain permission directly from the copyright holder. To view a copy of this licence, visit http://creativecommons.org/licenses/by/4.0/.

\section{References}

Acworth RI (1987) The development of crystalline basement aquifers in tropical environments. Q J Eng Geol Lond 20:265-272

Adelana SMA, Olaseinde PI, Vrbka P (2003) Groundwater recharge pattern in the Cretaceous and Tertiary sediment aquifers of northwestern Nigeria, using hydrochemical and isotopic techniques. In: Bocanegra E, Martinez D, Massone H (eds) Groundwater and human development, Mar de Plata, Argentina. CRC Press, Boca Raton, pp 907-915

Adelana SMA, Bale RB, Wu M (2004) Water quality in a growing urban centre along the coast of south western Nigeria. In: Seilder $\mathrm{KPW}$, Xi R (eds) Research basic and hydrological planning. Balkema, Rotterdam, pp 83-92

Adelana SMA, Olasehinde PI, Vrbka P (2005) A quantitative estimation of groundwater recharge in part of the Sokoto basin, Nigeria. J Environ Hydrol 14(5):1-16

Adelana SMA, Abiye TA, Nkhuwa C, Tindinugaya C, Oga MS (2008) Urban groundwater management and protection in Sub-Saharan Africa. In: Adelana SMA, MacDonald AM (eds) Applied groundwater studies in Africa. International Association of Hydrogeologists, Reading, pp 222-259 (selected papers)

Adewumi AJ, Anifowose AYB, Olabode FO, Laniyan TA (2018) Hydrogeochemical characterization and vulnerability assessment of shallow groundwater in Basement Complex Area, Southwest Nigeria. Contemp Trends Geosci 7(1):72-103

Ajala O (2005) Environmental impact of urbanization, culture and the Nigeria. In: Fadare $\mathrm{O}$ et al (eds) Globalization, culture and Nigerian built environment. Faculty of Environmental Design and Management, OAU, Ife, pp 192-199 
Akintorinwa OJ, Olowolafe TS (2012) Geoelectric evaluation of groundwater prospect within Zion Estate, Akure, Southwest, Nigeria. Int J Water Resour Environ Eng 5(1):12-28

Akujieze CN, Coker SJL, Oteze GE (2003) Groundwater in Nigeria. A Millenium experience distribution practice, problems and solutions. Hydrogeol J 11(2):259-274

Aladejana OO, Anifowose AYB, Fagbohun BJ (2016) Testing the ability of an empirical hydrological model to verify a knowledgebased groundwater potential zone mapping methodology. Model Earth Syst Environ 2(174):1-17

Aller L, Bennet T, Lehr JH, Petty RJ, Hackett G (1987) DRASTIC: a standardized system for evaluating ground water pollution potential using hydrogeologic settings. US EPA report 600/2-87/035, U.S. Environmental Protection Agency. http://www.epa.gov/nscep . Retrieved 14 July 2009

Anifowose AYB (2000) Stabilization of lateritic soils as a raw material for building blocks. Bull Eng Geol Environ 58:151-157

Anifowose, AYB, Kolawole F (2012) Tectonohydrological study of Akure metropolis, Southwestern Nigeria. Special publication of the Nigerian Association of Hydrological Sciences. Hydrology for Disaster Management, pp 106-120

APHA (1995) Standard methods for the examination of water and waste water, 19th edn. American Public Health Association, Washington, DC, pp 1-67

Asiwaju-Bello YA, Olabode FO, Duvbiama OA, Iyamu OI, Adeyemo AA, Onigbinde MT (2013) Hydrochemical evaluation of groundwater in Akure Area, South-western Nigeria, for irrigation purpose. Eur Int J Sci Technol 2(8):235-249

Batabyal AK (2017) Hydrogeochemical processes and contaminants enrichment with special emphasis on fluoride in groundwater of Birbhum district, West Bengal, India. Environ Earth Sci 76:285

Batabyal AK, Chakraborty S (2015) Hydrogeochemistry and water quality index in the assessment of groundwater quality for drinking purposes. Water Environ Res 87(7):608-617

Berner EK, Berner RA (1987) The global water cycle, geochemistry and environment. Prentice-Hall, Upper Saddle River, pp 1-453

Bozdag A (2016) Assessment of the hydrogeochemical characteristics of groundwater in two aquifer systems in Cumra Plain, Central Anatolia. Environ Earth Sci 75(674):1-15

Chatfield C, Collin AJ (1980) Introduction to multivariate analysis. Chapman and Hall in association with Methuen, Inc., New York

Deshmukh DS, Chaube UC, Hailu AE, Gudeta DA, Kassa MT (2013) Estimation and comparison of curve numbers based on dynamic land use land cover change, observed rainfall-runoff data and land slope. J Hydrol 492:89-101

Elango L, Rannan R, Senthil KM (2003) Major ion chemistry and identification of hydrogeochemical processes of groundwater in a part of Kancheepuram district, Tamil Nadu, India. J Environ Geosci 10:157-166

Eni DV, Obiefuna J, Oko C, Ekwok I (2011) Impact of urbanization on sub-surface water quality in Calabar municipality, Nigeria. Int J Humanit Soc Sci 10(1):167-172

Fagbohun BJ, Olabode OF, Adebola AO, Akinluyi FO (2017) GISbased sub-basin scale identification of dominant runoff processes for soil and water management in Anambra area of Nigeria. Contemp Trends Geosci 6(2):80-93

Faniran A (1970) Landform examples from Nigeria No. 2. The deep weathering (Duricrust) profile. Niger Geogr J 13:87-88

Fetter CW (1994) Applied hydrogeology, 3rd edn. Prentice Hall, Eaglewood Cliffs

Foster S, Lawrence A, Morris B (1998) Groundwater in urban development: assessing management needs and formulating policy strategies. World Bank technical document, No. 390, Washington, DC

Freeze RA, Cherry JA (1979) Groundwater. Prentice Hall, Eaglewood Cliffs, NJ
Gbadebo AM, Oyedepo JA, Taiwo AM (2010) Variability of nitrate in groundwater in some parts of Southwestern Nigeria. Pac J Sci Technol 11(2):572-584

Gibbs RJ (1970) Mechanism controlling world water chemistry. Sciences 170:795-840

Hem JD (1991) Study and interpretation of the chemical characteristics of natural waters, 3rd edn. Scientific Publishers, Jodhpur

Hernandez-Espriu HA, Reyna-Gutierrez J, Sanchez-Leoon E, Cabral-Cano E, Carrera-Hernandez J, Martinez-Santos P, Macias-Medrano S, Falorni G, Colombo D (2014) The DRASTIC-Sg model: an extension to the DRASTIC approach for mapping groundwater vulnerability in aquifers subject to differential land subsidence, with application to Mexico City. Hydrogeol J 22:1469-1485

Ikem A, Osibanjo O, Srodhar MKC, Sobande A (2002) Evaluation of groundwater quality characteristics near two waste sites in Ibadan and Lagos, Nigeria. Water Air Soil Pollut 140(1-4):307-3333

Jacks G (1973) Chemistry of groundwater in a district in southern India. J Hydrol 18:185-200

Jeyaraj T, Padmavathy S, Jebakumari S (2006) Correlation between water quality parameters for groundwater samples of Bharathi Nagar, Tiruchirappalli City. Indian J Environ Prot 22(7):755-769

Kehinde MO (1998) The impact of industrial growth on groundwater quality and availability. In: Osuntokun A (ed) Current issues in Nigerian environment. Ibadan Danidan Press, Ibadan

Khan TA (2015) Groundwater quality evaluation using multivariate methods, in parts of Ganga Sot Sub-basin, Ganga Basin, India. J Water Resour Prot 7:769-780

Kirshna Kumar S, Logeshkumaran A, Magesh NS, Godson PS, Chandrasekar N (2014) Hydro-geochemistry and application of water quality index (WQI) for groundwater quality assessment, Anna Nagar, part of Chennai City, Tamil Nadu, India. Appl Water Sci. https://doi.org/10.1007/s13201-014-0196-4

Laniyan TA, Ajibade OM, Bayewa OO, Oshomoji AO (2015) Impact of urban activities on groundwater qualities in Abeokuta Southwestern Nigeria. Ife J Sci 17(2):239-246

Lapworth DJ, Krishan G, MacDonald AM, Rao MS (2017) Groundwater quality in the alluvial aquifer system of northwest India: new evidence of the extent of anthropogenic and geogenic contamination. Sci Total Environ 599-600:1433-1444

Lawrence FW, Upchurch SB (1982) Identification of recharge areas using geochemical factor analysis. Groundwater 20(6):680-687

MacDonald A, Davis J, Calow Chilton J (2005) Developing groundwater: a guide to rural water supply. ITDGS Publishing, West Yorkshire

Mahmoud SH (2014) Delineation of potential sites for groundwater recharge using a GIS-based decision support system. Environ Earth Sci 72(1):3429-3442

Marghade DT (2015) Identification of controlling processes of groundwater quality in a developing urban area using principal component analysis. Environ Earth Sci 74:5919-5933

Naidu R, Datta B, Chadalavada S (2011) Optimization approach for pollution sources identification approach for pollution source identification in groundwater an overview. Int $\mathbf{J}$ Environ Waste Manag 8:40-41

Nigeria Geological Survey Agency (NGSA) (2006) Published by the Authority of the Federal Republic of Nigeria

Nwankwor GI, Egboka BC, Orajaka IP (1988) Groundwater occurrence and flow pattern in the Enugu coal-mine area, Anambra State, Nigeria. Hydrol Sci J 33(5):465-482

Ocheri MI (2006) Analysis of water consumption pattern in Makurdi Metropolis. J Geogr Dev 1:71-83 
Ocheri MI, Mile II (2010) Spatial and temporal variation in groundwater quality of Makurdi sedimentary formation. J Geogr Environ Plan 6(1):141-146

Ocheri MI, Odoma LA, Umar ND (2014) Groundwater quality in Nigerian urban areas: a review. Glob J Sci Front Res (H) 14(3):34-46

Offodile ME (2014) Hydrogeology: groundwater study and development in Nigeria, 3rd edn. Mecon Geology and Engineering Services Ltd., Jos

Oke SA (2015) Evaluation of the vulnerability of selected Aquifer Systems in the Eastern Dahomey Basin. Unpublished Ph.D. thesis, Faculty of Natural and Agricultural Sciences (Institute for Groundwater Studies), University of the Free State

Olabode OF (2019) Potential groundwater recharge sites mapping in a typical basement terrain: a GIS methodology approach. J Geovis Spat Anal. https://doi.org/10.1007/s41651-019-0028-z

Olofinlade WS, Daramola SO, Olabode OF (2018) Hydrochemical and statistical modeling of groundwater quality in two contrasting geological terrains of southwestern Nigera. Model Earth Syst Environ 4(4): 1405-1421

Olorunfemi MO, Ojo JS, Akintunde OM (1999) Hydro-Geophysical evaluation of the groundwater potentials of the Akure Metropolis, Southwestern Nigeria. J Min Geol 35(2):207-228

Ondo State Ministry of Economic Planning and Budget (2012) The publication of facts and figures of Ondo State of Nigeria. Research and Statistics Department, Akure, pp 7-9

Ondo State Ministry of Lands, Housing and Environment (2000) Ecological report and engineering design for flood and erosion control works in Idanre township. MLHE, Akure

Owoseni JO, Komolafe AA (2014) The role of groundwater vulnerability in land use and urban development planning. In: Olujimi $\mathrm{JAB}$, Ogunsote OO, Awodele AO (eds) Infrastructure, economic development and built environment: a book of readings. School of Environmental Technology, Federal University of Technology, Akure, Nigeria, Akure, pp 431-440

Owoseni JO, Tamarautobou EH, Asiwaju-bello YA (2013) Application of sequential analysis and geographic information systems for hydrochemical evolution survey, Shagari Environ, Southwestern Nigeria. Am Int J Contem Res 5(5):38-48

Oyedele AA, Ayodele OS, Olabode OF (2019) Groundwater quality assessment and characterization of shallow basement aquifers in parts of Ado Ekiti Metropolis, southwestern Nigeria. SN Appl Sci. https://doi.org/10.1007/s42452-019-0683-1

Piper AM (1944) A graphic procedure in geochemical interpretation of water analysis. Trans Am Geophys Union 25(6):914-928

Punmia BC, Jain AK (1998) Wastewater engineering. Laxmi Publications (P) Ltd, New Delhi
Rahaman MA (1976) Review of the basement Geology of the southwestern Nigeria. In: Kogbe CA (ed) Geology of Nigeria. Elizabethan Publishing Co., Lagos, pp 4-58

Rogers RJ (1989) Geochemical comparison of groundwater in areas of New England, New York, and Pennyslvania. Groundwater 27:690-712

Schoeller H (1967) Qualitative evaluation of groundwater resources, methods and techniques of groundwater investigation and development. Water research, series-33. UNESCO, pp 45-52

Senanayake IP, Dissanayake DMDOK, Mayadunna BB, Weerasekera WL (2016) An approach to delineate groundwater recharge potential sites in Ambalantota, Sri Lanka using GIS techniques. Geosci Front 7:115-124

Smyth AJ, Montgomery RF (1962) Soils and land use in central western Nigeria. The Government Printers Ibadan, Ibadan

Soulis KX, Valiantzas JD (2012) SCS-CN parameter determination using rainfall-runoff data in heterogenous watersheds-the two-CN system approach. Hydrol Earth Syst Sci 16(3):1001-1015

Sridhar MKC (2000) Groundwater in Nigerian urban centers: problems and options. Schriftenr Ver WasserBoden Luftyg 105:393-397

Subba Rao N (2002) Geochemistry of groundwater in parts of Guntur district, Andhra Pradesh, India. Environ Geol 41:552-562

United Nations Department of Economic and Social Affairs Population Division (2015) World population prospects: the 2015 revision, methodology of the United Nations population estimates and projections, working paper no. ESA/P/WP242

Vasanthavigar M, Srinivasmoorthy K, Vijayaragavan K, Rajivganthi R, Chidambaram S, Anandhan P, Manivannan R, Vasudevan S (2010) Application of water quality index for groundwater quality assessment: Thirunmanimuttar Sub-basin, Tamil Nadu, India. Environ Monit Assess 17(1-4):595-609

Villumsen A, Jacobsen OS, Sonderskov C (1983) Mapping the vulnerability of groundwater reservoirs with regard to surface pollution. Damm Geol Unders Arbog Kobenhavn 2:17-38

World Health Organization (2011) Guidelines for drinking water quality, 4th edn. Switzerland, Geneva

Yenne EY, Anifowose AYB, Yohanna MO (2018) An integrated exploration technique for groundwater on a part of the basement complex of southwestern Nigeria. Glob J Geol Sci 16:45-61

Publisher's Note Springer Nature remains neutral with regard to jurisdictional claims in published maps and institutional affiliations. 